\title{
Prodrugs for Gene-Directed Enzyme-Prodrug Therapy (Suicide Gene Therapy)
}

\author{
William A. Denny* \\ Auckland Cancer Society Research Centre, School of Medical \& Health Sciences, \\ The University of Auckland, Private Bag 92019, Auckland 1000, New Zealand
}

Received 17 June 2002; accepted 19 July 2002

\begin{abstract}
This review focuses on the prodrugs used in suicide gene therapy. These prodrugs need to satisfy a number of criteria. They must be efficient and selective substrates for the activating enzyme, and be metabolized to potent cytotoxins preferably able to kill cells at all stages of the cell cycle. Both prodrugs and their activated species should have good distributive properties, so that the resulting bystander effects can maximize the effectiveness of the therapy, since gene transduction efficiencies are generally low. A total of 42 prodrugs explored for use in suicide gene therapy with 12 different enzymes are discussed, particularly in terms of their physiocochemical properties. An important parameter in determining bystander effects generated by passive diffusion is the lipophilicity of the activated form, a property conveniently compared by diffusion coefficients $\left(\log \mathrm{P}\right.$ for nonionizable compounds and $\log \mathrm{D}_{7}$ for compounds containing an ionizable centre). Many of the early antimetabolite-based prodrugs provide very polar activated forms that have limited abilities to diffuse across cell membranes, and rely on gap junctions between cells for their bystander effects. Several later studies have shown that more lipophilic, neutral compounds have superior diffusion-based bystander effects. Prodrugs of DNA alkylating agents, that are less cell cycle-specific than antimetabolites and more effective against noncycling tumor cells, appear in general to be more active prodrugs, requiring less prolonged dosing schedules to be effective. It is expected that continued studies to optimize the bystander effects and other properties of prodrugs and the activated species they generate will contribute to improvements in the effectiveness of suicide gene therapy.
\end{abstract}

\section{INTRODUCTION}

Gene-directed enzyme-prodrug therapy (GDEPT) or suicide gene therapy is comprised of three components; the prodrug to be activated, the enzyme (usually nonhuman) used for activation, and the delivery system for the corresponding gene [1]. Most attention to date has been directed towards development of the vector systems, on which there is a large literature. This review focuses on the small molecule prodrugs used in such therapies. Prodrugs can be considered as comprised of two major domains; a "trigger" unit that is the substrate for the activating enzyme, and an "effector" unit that is activated or released by this metabolic process, sometimes joined by a definable linker [2] (Figure 1).

As well as being an efficient and selective substrate for the activating enzyme, the prodrug itself needs to be a systemic agent, metabolically stable and able to diffuse efficiently by paracellular and/or transcellular routes to the areas in the tumor where the activating enzyme is being generated. The effector that is activated or released from the prodrug must be an effective cytotoxin (preferably able to kill cells at all stages of the cell cycle), but must also have good bystander effects (an ability to diffuse to and kill neighbouring tumor cells). Most delivery

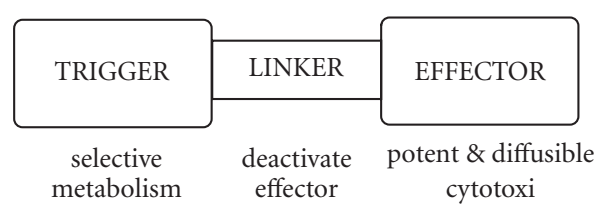

FIGURE 1. Trigger-linker-effector concept for prodrug design.

systems still have very low efficiencies of gene transduction, and the bystander effect of the effector species is important in compensating for this [3]. The physicochemical properties that govern these desirable pharmacokinetic characteristics of both prodrugs and effectors are beginning to be understood, and include molecular size, overall lipophilicity, charge, rate of metabolism, and the propensity to form reversible or irreversible complexes with cellular macromolecules.

The next section provides a brief overview of prodrugs that have been explored for use in GDEPT, and their corresponding effectors. These are grouped according to the activating enzyme, and do not provide extensive details of relative levels of use but focus on the chemistry of the prodrugs. Table 1 provides a broad categorization of the DNA binding of the prodrugs (and their activated forms) 
TABLE 1. Estimated physicochemical properties governing the bystander effects of GDEPT prodrugs and their principal effectors.

\begin{tabular}{|c|c|c|c|c|c|}
\hline \multicolumn{3}{|c|}{ Prodrug } & \multicolumn{3}{|c|}{ Effector } \\
\hline No & $\log \mathrm{P}^{\mathrm{a}}$ & $\mathrm{DNA}^{\mathrm{b}}$ & No & $\log \mathrm{P}^{\mathrm{a}}$ & $\mathrm{DNA}^{\mathrm{b}}$ \\
\hline $\mathbf{1 a}(\mathrm{GCV})$ & -2.07 & low & $1 b$ & $-6.70^{c}$ & low \\
\hline 2a (E-GCV) & 7.0 & low & $1 b$ & $-6.70^{c}$ & low \\
\hline $3 \mathbf{a}(\mathrm{PCV})$ & -2.03 & low & $3 b$ & $-6.71^{\mathrm{c}}$ & low \\
\hline $4 \mathbf{a}(\mathrm{ACV})$ & -1.76 & low & $4 \mathrm{~b}$ & $-6.34^{\mathrm{c}}$ & low \\
\hline $5 \mathbf{a}(\mathrm{VCV})$ & -0.78 & low & $4 b$ & $-6.34^{\mathrm{c}}$ & low \\
\hline 6a (BVDU) & -0.43 & low & $6 \mathrm{~b}$ & $-5.25^{\mathrm{c}}$ & low \\
\hline $7 \mathbf{a}(\mathrm{AZT})$ & -0.58 & low & $7 \mathrm{~b}$ & -5.46 & low \\
\hline $\mathbf{8 a}(\mathrm{MCT})$ & -1.77 & low & $8 b$ & $-6.49^{c}$ & low \\
\hline $9 \mathbf{a}(5-\mathrm{FC})$ & $-1.79^{c}$ & low & $9 b(5-F U)$ & $-2.17^{c}$ & low \\
\hline 10a (MEP) & -0.35 & low & $10 \mathrm{~b}$ & $0.09^{c}$ & low \\
\hline 11a (FAMP) & -2.32 & low & $11 \mathrm{~b}$ & $-1.26^{\mathrm{c}}$ & low \\
\hline 12a (CPA) & 0.23 & low & $12 b$ & $-3.95^{\mathrm{c}}$ & bond $^{\mathrm{d}}$ \\
\hline $13 \mathbf{a}(\mathrm{IFO})$ & 0.50 & low & $12 b$ & $-3.95^{\mathrm{c}}$ & bond $^{\mathrm{d}}$ \\
\hline $14 \mathrm{a}$ & 0.34 & low & 14b (NABQI) & 0.38 & bond $^{\mathrm{d}}$ \\
\hline 15a (4-IM) & 0.70 & low & unknown & - & bond $^{\mathrm{d}}$ \\
\hline 16a (CMDA) & $-4.67^{\mathrm{c}}$ & low & $16 \mathrm{~b}$ & 0.05 & bond $^{\mathrm{d}}$ \\
\hline $17 \mathrm{a}$ & $-3.09^{c}$ & low & $17 \mathrm{~b}$ & 1.66 & bond $^{\mathrm{d}}$ \\
\hline $18 \mathrm{a}$ & $-1.62^{\mathrm{c}}$ & low & $18 b$ & 3.73 & bond $^{\mathrm{d}}$ \\
\hline $19 \mathrm{a}$ & $\sim 3.0$ & high & 19b (DOX) & $0.34^{\mathrm{c}}$ & high \\
\hline 20a (MTX-Phe) & 2.74 & low & $20 \mathrm{~b}$ (MTX) & -0.28 & low \\
\hline 21a (IRT) & $1.54^{\mathrm{c}}$ & low & $21 \mathbf{b}(\mathrm{SN}-38)$ & 2.02 & low \\
\hline $22 a$ & $2.04^{\mathrm{c}}$ & high & $22 \mathrm{~b}$ & $1.51^{\mathrm{c}}$ & bond $^{\mathrm{d}}$ \\
\hline 23a (CB1954) & 1.28 & low & $23 b$ & -0.34 & bond $^{\mathrm{d}}$ \\
\hline 24a (SN23862) & 2.06 & low & $24 b$ & 2.50 & bond $^{\mathrm{d}}$ \\
\hline $29 a$ & 4.40 & medium & $29 b$ & 4.13 & medium \\
\hline $32 \mathrm{a}$ & 4.55 & medium & $32 b$ & 1.87 & bond $^{\mathrm{d}}$ \\
\hline $35 \mathbf{a}$ (IAA) & $-0.81^{\mathrm{c}}$ & low & $35 b$ & 1.35 & high \\
\hline 36a (FIAA) & $-1.09^{c}$ & low & $36 \mathrm{~b}$ & 1.80 & bond $^{\mathrm{d}}$ \\
\hline 37a (6-TX) & $-0.41^{\mathrm{c}}$ & low & $37 b$ & $-5.52^{\mathrm{c}}$ & low \\
\hline 38a (HM1826) & 1.53 & high & $19 b$ & $0.36^{c}$ & high \\
\hline $39 a$ & 0.78 & high & $22 b$ & 1.51 & bond $^{\mathrm{d}}$ \\
\hline $40 \mathrm{a}$ & 0.78 & high & $22 b$ & 1.51 & bond $^{\mathrm{d}}$ \\
\hline $41 \mathrm{a}\left(5^{\prime}\right.$-DFUR) & -0.82 & low & $9 \mathrm{~b}$ & $-2.17^{\mathrm{c}}$ & low \\
\hline 42a (SeMET) & $-3.15^{\mathrm{c}}$ & low & $42 b$ & $0.72^{\mathrm{d}, \mathrm{e}}$ & low \\
\hline
\end{tabular}

a Calculated using Advanced Chemistry Development (ACD) Software 5.0 package.

b Estimate (based on structure only) of the level of reversible binding to DNA.

$\mathrm{c} \log \mathrm{D}$ at $\mathrm{pH} 7$ for compounds with ionizable groups.

$\mathrm{d}$ Covalent alkylation of DNA.

e Calculated for $\mathrm{S}$ analogue.

discussed here, based on the knowledge of their structure. Most have little or no ability to bind reversibly to DNA, some are likely to have significant binding constants, and many (especially the activated forms) can covalently react with DNA. Since both reversible and irreversible binding lower the free drug concentration that drives diffusion, the level of DNA binding can significantly influence the bystander effect. The lipophilicity of both the prodrug and the activated drug also has an important influence on bystander abilities [4]. Table 1 contains $\log \mathrm{P}$ values 
(n-octanol/water partition coefficents) for the compounds, calculated using the Advanced Chemistry Development (ACD) 5.0 Software package. These calculated values are approximations, and can differ substantially from measured values in some series, but in the absence of measured values for most of the compounds serve to at least rank the compounds overall. For those possessing ionizable centres, $\log \mathrm{D}_{7}$ values are used; these take into account the $\log \mathrm{P}$ values of the neutral and ionized forms and the relative proportions of each at $\mathrm{pH} 7$.

\section{PRODRUGS FOR THYMIDINE KINASE (TK)}

\section{Introduction}

The most prominent GDEPT therapy has been the use of the herpes simplex type-1 thymidine kinase enzyme (HSV-Tk) in conjunction with a variety of guanosinebased prodrugs, compounds originally developed as antiviral (anti-herpes) agents $[5,6]$. The enzyme converts these prodrugs very efficiently (much more efficiently than the corresponding endogenous kinases) to the monophosphates, which are then converted by cellular enzymes to the toxic triphosphates (Figure 2). These cause cell death by inhibition of incorporation of dGTP into DNA, and also by prevention of chain elongation [7]. Fusion proteins of HSV-Tk with green fluorescent protein showed that enzyme expression was predominantly in the nucleus of both transduced human and rodent glioma cells [8]. A study using positron-emission tomography (PET) showed that the extent of gene expression correlated with therapeutic response in glioma [9].

\section{Ganciclovir (GCV; 1a)}

This is the most widely used prodrug for HSV-Tk, and is well known in its own right as an antiviral agent [6]. It is a very hydrophilic compound (calculated $\log \mathrm{P}-$ 2.07; see Table 1). The HSV-Tk enzyme converts this to the monophosphate (1b) which can then be converted by cellular enzymes to the toxic triphosphate (Figure 2). The high cytotoxicity shown by GCV in HSV-Tk transduced cells is suggested to be due to its enhanced ability, compared to related prodrugs, to incorporate into DNA without inhibiting progression through the S-phase [10]. In $\mathrm{CHO}$ cells, GCV is a potent inducer of chromosome breaks and sister chromatid exchange at concentrations well below those required for its gene therapy activity [11].

The monophosphate effector $\mathbf{1} \mathbf{b}$ is more polar than GCV even as the neutral form $(\log \mathrm{P}=-2.6)$, but is also partially ionized to an anionic species, giving a calculated partition coefficient at pH $7\left(\log \mathrm{D}_{7}\right)$ of -6.7 (Table 1). Although this species has very limited ability to cross cell membranes by passive diffusion, HSV-Tk/GCV therapy demonstrates bystander effects in a number of models. Numerous studies have shown this is mediated primarily by gap junctional intercellular communication (GJIC)
$[7,12,13]$. Because extensive gap junction networks are not common in tumors, a variety of methods to augment HSV-Tk/GCV therapy have been explored [7]. There is also extensive evidence of an immunological component to the bystander effect in vivo, in that along with the regression of HSV-tk transduced tumors, distant nontransduced tumors also show significant effects [14]. A $\mathrm{T}_{\mathrm{H}} 1$ based immune response was seen in rat prostate cancer models undergoing HSV-Tk/GCV therapy [15], and a clinical study also showed elevated numbers of peripheral $\mathrm{T}$ and $\mathrm{B}$ cells, enhanced T-cell activation, and elevated serum levels of interleukin 12 during intracranial GCV treatment [16].

The major clinical use of GCV in GDEPT has been in glioblastoma, using direct injection of the tumor with the vector, followed by systemic administration of prodrug. The drug is well-tolerated, but there have been varied reports of its utility, including a recent large multicenter stage-III trial on 248 patients with newly diagnosed, previously untreated glioblastoma multiforme [17]. This trial found no benefit in either time to tumor progression nor overall survival time compared to best available therapy (surgical resection and radiotherapy), attributed to the poor rate of delivery of the HSV-tk gene, and possibly poor delivery of the prodrug across the blood-brain and blood-tumor barriers.

Another approach to improving therapy with GCV is the use of mutant enzymes. Several studies have showed that random [18] or semirandom [19] mutagenesis of the wild-type enzyme can provide substantial increases in both in vitro and in vivo activity, allowing lower and less immunosuppressive doses of GCV to be used. A number of mutation sites (eg, at Gln-125 and Ala-168) result in higher $\mathrm{Km}$ values for thymidine binding due to loss of $\mathrm{H}$ bond contacts, and unaltered or even improved binding for GCV $[20,21]$. This results in reduced competition between prodrug and thymidine at the active site, providing improved kinetics of conversion of GCV.

Combination therapy with HSV-Tk/GCV and other agents have also been explored. Some of these, like proteases such as trypsin or collagenase/dispase [22] are designed to improve gene delivery. Others are designed to complement the effects of the activated drug, such as stimulation of the immune system with GM-CSF in [23], which showed increased cure rates in animal models. Radiation therapy has been used both to upregulate promotors to increase gene expression [24] and to enhance the cytotoxicity of the activated drug [25]. In HSV-Tk transduced mouse RM-1 prostate cancer cells, the combination of GCV and radiation was additive at low doses of radiation, and possibly synergistic above doses of 8 Gy [26]. Retinoids increase GJIC by induction of connexin expression, and augment the efficiency of cell killing by GCV in HSV-YK transduced cell lines [27].

A variety of thymidylate synthase inhibitors, including Tomudex, 5-fluorouracil (5-FU) and (E)-5-(2bromovinyl)-2'-deoxyuridine (BVDU) show synergistic 


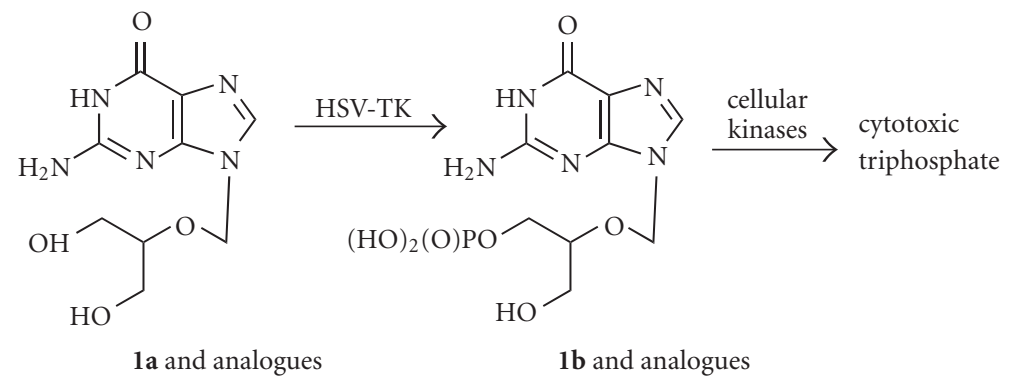<smiles>[R9]CC(CO)OCn1cnc2c(=O)[nH]c(N)nc21</smiles><smiles>Nc1nc2c(ncn2CCC(CO)CO)c(=O)[nH]1</smiles><smiles>[R6]CCOCn1cnc2c(=O)[nH]c(N)nc21</smiles>

$2 \mathrm{a}: \mathrm{R}=\mathrm{CO}\left(\mathrm{CH}_{2}\right)_{7} \mathrm{CH}=\mathrm{CH}\left(\mathrm{CH}_{2}\right)_{7} \mathrm{Me}$<smiles>Cc1cn([C@@H]2C[C@H](N)[C@@H](CO)O2)c(=O)[nH]c1=O</smiles><smiles>Cc1cn([C@@H]2C[C@H](O)C2(CO)CO)c(=O)[nH]c1=O</smiles>

Figure 2. Activation of ganciclovir and analogues by HSV-Tk.

cell killing when used with GCV in clonogenic assay studies, while a combination of GCV and 5-FU provided significantly-enhanced survival rates in an sc HT29 STK tumor xenograft model in mice [28]. Combinations of GCV and the topoisomerase I inhibitor topotecan also showed synergistic cell killing in HSV-Tk transduced murine MC38 and human HT-29 colon carcinoma cell lines in a clonogenic assay, and were superior to GCV alone in sc tumor xenograft models using the same cell lines in athymic nude mice [29].

\section{Ganciclovir elaidic acid ester (E-GCV; $2 a)$}

This very lipophilic $(\log \mathrm{P}+7.0)$ preprodrug of GCV is more potent than GCV itself in cell cultures $\left(\mathrm{EC}_{50}\right.$ for $\mathrm{E}$ GVC around $2 \mathrm{nmol}$ ), with a selectivity index $\left(\mathrm{IC}_{50}\right.$ ratio) in FM3Atk-/HSV-1tk+ cells of $>2000$ fold. Nonspecific hydrolysis of the ester gives GCV, and both GCV and EGCV were converted to the mono-, di-, and triphosphates of GCV. However, the half-lives of both GCV and its phosphate metabolites were much longer (about 50 hours) in cells treated with E-GCV rather than GCV, suggesting the possible utility of lipophilic preprodrugs for modulating pharmacokinetics [30].

\section{Penciclovir (PCV; 3a)}

This prodrug is closely related to GVC, with the ether replaced by a $\mathrm{CH}_{2}$ group, and has similarly low lipophilicity $(\log \mathrm{P}-2.03)$. PCV is less genoxic than GCV or $\mathrm{ACV}$, inducing sister chromatid exchanges only at cytotoxic/apoptotic concentrations, and is only weakly clastogenic [11]. Treatment of HSV-Tk transformed baby hamster kidney cells with PCV and GCV, but not ACV, induced rapid accumulation of cells in the S-phase and apoptotic death as measured by the TUNEL assay [31], and this property, together with the low genotoxicity of PCV, makes it a relatively safe alternative drug for suicide gene therapy [32].

\section{Acyclovir (ACV; 4a)}

As Zovirax, ACV is the most frequently used antiherpes drug. It is closely-related chemically to GCV, but is slightly more lipophilic $(\log \mathrm{P}-1.76)$ due to one less alcohol group. ACV is a moderate genotoxin in $\mathrm{CHO}$ cells, inducing chromosomal aberrations and sister chromatid exchange but only at concentrations much higher than those achieved in blood plasma in vivo [11]. Comparative studies have generally shown it to be an effective prodrug 
for HSV-Tk, both less toxic and less potent and (perhaps surprisingly in view of its higher lipophilicity) with lower bystander effects. However, in a study using ovarian cancer cell lines and comparing ACV and GCV at equal concentrations, the former showed equal or higher cell killing efficacy and bystander effects [33]. In other studies using U251tk human glioblastoma cells stably expressing HSVTk, ACV gave a lesser cell kill than did GCV $(<1.5 \mathrm{log}$ compared to $>4 \log$ ) [10]. As with GCV, ACV sensitizes HSV-Tk transduced cells to radiation [34]. Clinical studies of patients with recurrent ovarian cancer treated with a replication-deficient HSV-tk gene vector, ACV and the topoisomerase I inhibitor topotecan showed median overall survival comparable to that of patients treated with conventional chemotherapy [35].

\section{Valacyclovir (VCV; 5a)}

Valacyclovir is a valine ester preprodrug form of ACV, which can be given orally. It is relatively lipophilic, although partial ionization of the amine counteracts this to some extent $\left(\log \mathrm{D}_{7}=-0.78\right)$. In a clinical study of recurrent ovarian cancer treated with an IP-injected HSV-tk vector followed by topotecan and either IV ACV or oral $\mathrm{VCV}$, the levels of ACV and VCV (measured as released $\mathrm{ACV}$ ) were similar, suggesting the use of VCV as a costeffective alternative in outpatient therapy [36]. Clinical trials of VCV and a locally-injected replication-deficient HSV-tk vector in prostate cancer, with [37] or without [38] concomitant radiation therapy, are in progress.

\section{(E)-5-(2-bromovinyl)-2' -deoxyuridine (BVDU; 6a)}

This is a potent antiherpes agent recently also used as a prodrug in gene therapy, and is considerably more lipophilic than GCV $(\log \mathrm{P}=-0.43)$. An efficient synthesis has been reported [39]. BVDU exerts its cytotoxic effect not only by incorporation into replicating DNA, but also through inhibition of thymidylate synthase. It enhances the GCV-induced killing of HSV-Tk transduced glioma cells [40], although BVDU itself is reported to have a poor bystander effect, both in vitro $[41,42]$ and in vivo [43]. It is a particularly good substrate for the varicella zoster virus thymidine kinase (VSV-Tk). While GCV was not toxic in VSV-Tk transduced MCF7, T-47D, and MDAMB-435 breast cancer cells, BVDU showed high cytotoxicity ( $\mathrm{IC}_{50} \mathrm{~s} 600,100$, and $60 \mathrm{nmol}$, respectively) and selectivity indices $\left(\mathrm{IC}_{50}\right.$ ratios of wild-type to VZV-Tk cells of 400, 750, and 2000, respectively). Bystander effects were not observed in vitro in MDA-MB-435 cells, but were seen in 9L rat gliosarcoma cells [44]. BVDU showed radiosensitizing activity in U-251 human glioma cells transduced with HSV-Tk, giving a sensitization enhancement ratio of 1.9 .

\section{Zidovudine (AZT; 7a)}

While the anti-AIDS drug AZT is a relatively poor substrate for HSV-Tk, its antimetabolite-type mechanism of action is similar to that of the guanosine analogues antiherpes drugs discussed above, and its lipophilicity is $(\log \mathrm{P}-0.58)$ similar to that of BVDU. Genetic modification of HSV-Tk produced mutants with reduced specificity for thymidine and much greater ability to phosphorylate AZT, due to active site mutations that better accommodate the azido group of AZT at the expense of thymidine [45].

\section{2'-Exo-methanocarbathymidine (MCT; 8a)}

The potent antiviral drug MCT is a substrate for HSV1-Tk [46], but a better one (12-fold increase in $K_{M}$ ) for the Y101F mutant. Crystal structure studies [47] of MCT with both enzymes show that the thymine moiety of MCT binds similarly to deoxythymidine, with the conformationally restricted bicyclo[3.1.0] hexane mimicking the sugar moiety. In MC38/HSV1-Tk murine colon cancer cells, MCT had an $\mathrm{IC}_{50}$ of $2.9 \mu \mathrm{mol}$ (comparable to that of GCV), and was metabolized to the mono-, di-, and triphosphates. Treatment of MC38/HSV1-Tk tumors in C57/BL6 mice at $100 \mathrm{mg} / \mathrm{kg}$ twice daily caused complete inhibition of tumor growth [48].

\section{PRODRUGS FOR CYTOSINE DEAMINASE (CD)}

\section{Introduction}

After HSV-Tk, the cytosine deaminase gene is the next most widely studied for GDEPT. The enzyme (CD) encoded by this gene catalyzes the conversion of cytosine to uracil, and is an important member of the pyrimidine salvage pathway in prokaryotes and fungi, but is not present in multicellular eukaryotes. The crystal structure of E. coli CD has an $\alpha \beta-8$ barrel structure with similarity (structurally not sequence) to adenosine deaminase, but not to cytidine deaminase [49]. The enzyme is a hexamer, stabilized by domain swapping between enzyme subunits, and containing the active site in the mouth of the enzyme barrel. GDEPT therapy using CD has focused almost entirely on one prodrug, the clinically used antifungal agent 5-fluorocytosine.

\section{5-Fluorocytosine (5-FC; 9a)}

5 -Fluorocytosine is a relatively hydrophilic $(\log \mathrm{P}-$ 1.79) antifungal agent with low toxicity in humans, who lack an endogenous enzyme that can activate it efficiently. However, bacterial and yeast CD enzymes convert it efficiently to 5-fluorouracil (5-FU) (9b). Studies with tritiated-5-FC in a human glioblastoma cell line stably transfected with the E. coli gene for CD showed it entered the cells relatively slowly by passive diffusion, and showed rapid efflux, suggesting that transport of this quite hydrophilic prodrug may be a limiting factor [50]. The active form 5 -FC is also quite polar $\left(\log \mathrm{D}_{7}-2.29\right)$ but is a diffusible species that is itself the single most effective drug for colon cancer, being converted by cellular enzymes to the ribosyl monophosphate 5-FdUMP (Figure 3), which is an irreversible inhibitor of thymidylate synthetase. An NMR study of 5-FC in sc yeast CD-transfected human 


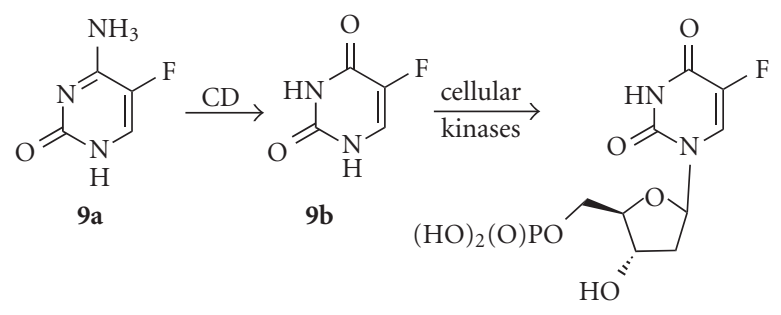

FIgUre 3. Activation of 5-FC by CD.

colorectal carcinoma xenografts in nude mice derived rate constants of $0.49 \mathrm{~min}^{-1}$ for CD-catalyzed prodrug conversion and $0.77 \mathrm{~min}^{-1}$ for 5 -FU efflux from the tumor volume [51]. In contrast to GCV, the bystander effects of $\mathrm{CD} / 5$-FC therapy do not depend on gap junctional intercellular communication (GJIC), and very large effects are seen with both communication-competent and -incompetent cells [52], mediated by the diffusion of 5FU. It has been suggested that CD/5-FU therapy in solid tumor models can generate complete cures if only $4 \%$ of the tumor cell mass express the enzyme [53].

$\mathrm{CD} / 5$-FC therapy has been studied, usually with the E. coli enzyme, in a wide variety of cancers, perhaps most notably colon using the carcinoembryonic antigen (CEA) promoter [53, 54]. MDA-MB-231 breast carcinoma cells transfected with E. coli $\mathrm{CD}$ were sensitized 1000 fold to 5 -FC in culture, with only $10 \%$ of the infected cells needed to induce complete cytotoxicity of in cocultures with noninfected cells. Sc MDA-MB-231 breast carcinoma xenografts in nude mice [55] and intracranial human glioma xenografts in scid mice [56] were controlled by an intratumoral dose of an adenovirus encoding E. coli $\mathrm{CD}$ and systemic 5-FU. Similar studies have shown the utility of $\mathrm{CD} / 5$-FC in hepatic metastases of colon carcinoma [57] and prostate cancer [58]. Studies using Saccharomyces cerevisiae CD, which has a $\mathrm{K}_{\mathrm{M}}$ for 5FC about 22-fold lower than that of $E$. coli CD show that this enzyme also shows superior results in sc HT29 human colon carcinoma xenografts [59], producing about 15 -fold more 5-FU in tumors at the same dose of 5-FC and greater radiosensitization [60]. When 5-FC/CD and HSV-Tk/GCV therapies were compared in a variety of in vivo models, both appeared of similar efficacy in hepatocellular carcinoma [61], but CD/5-FC was clearly superior in EBV-associated lymphomas [62], renal cell carcinoma [63], and colorectal carcinoma [64], attributed to its superior bystander effect.

Coexpression of CD together with E. coli uracil phosphoribosyltransferase (UPRT), which is absent in mammalian cells and which directly converts 5 -FU to the $5^{\prime}$ monophosphate ( $5^{\prime}$-FdUMP), is synergistic. 9L glioma cells expressing both enzymes were 375 -fold more sensitive to 5-FC than cells transduced with CD alone [65]. Cells expressing both enzymes showed large increases in 5-FdUMP, 5-fluorouridine triphosphate, incorporation into RNA and inhibition of thymidylate synthase [66]. Coexpression of both CD and HSV-Tk enzymes was also shown to be synergistic, both in vitro [68] and in sc rat 9L glioma tumors in nude mice [67] treated with 5-FC and GCV. The mechanism appears to be an enhancement of GCV phosphorylation by HSV-Tk following 5-FC treatment [68].

Combination studies of 5-FC with radiotherapy in CD-transfected tumors also show sensitization of sc xenografts of squamous cell carcinoma [69], cholangiocarcinoma [70] and colon carcinoma [71], using a dose of $800 \mathrm{mg} / \mathrm{kg} / \mathrm{day}$ of $5-\mathrm{FC}$ and from 10-50 Gy of tumor irradiation. Dose-modifying factors of up to 1.5 were observed. A Phase I clinical trial of CD linked to a tumorspecific erbB2 promotor in breast cancer patients showed significant levels of expression of the $\mathrm{CD}$ gene, restricted to erbB-2-positive tumor cells, in about 90\% of cases [72].

\section{PRODRUGS FOR PURINE NUCLEOSIDE PHOSPHORYLASE (PNP)}

\section{Introduction}

The E. coli purine nucleoside phosphorylase (PNP) is a hexameric enzyme that catalyzes the reversible phosphorolysis of 6-amino-2'-deoxyribonucleosides to the free base and 2'-deoxyribose-1-phosphates, whereas the corresponding (trimeric) human enzyme only hydrolyses 6-oxopurine nucleosides. Comparative crystal structures show that the active-site location and its overall geometry are similar for the E. coli and human enzymes, but the subunit interactions are quite different, with the E. coli enzyme having more hydrophobic purine- and ribosebinding sites [73].

\section{6-Methylpurine deoxyriboside (MEP; 10a)}

The most widely used prodrug for PNP in GDEPT is 6-methylpurine deoxyriboside (MEP) $\left(\log \mathrm{D}_{7}-0.35\right)$, which is converted by PNP to more lipophilic $\left(\log \mathrm{D}_{7}-\right.$ 0.09 ) and highly diffusible metabolite 10b (Figure 4). This has the potential advantages of being less cell cyclespecific than most antimetabolites and having excellent bystander effects. Human ovarian tumors transfected with E. coli PNP controlled by an SV40 promoter and implanted IP were shown to express PNP in only $0.1 \%$ of the cells after 5 days, yet treatment of these with MEP resulted in an average $49 \%$ reduction in tumor size and 30\% increase in life span compared with control tumors [74]. A comparison of MEP/PNP and GCV/HSV-Tk therapy in a PC-3 human androgen-independent prostate cancer cell line showed that MEP/PNP caused more rapid cell killing at a 5-10-fold lower input of virus [75]. Against the same cells as sc tumors in nude mice, both systems showed comparable activity, holding tumor growth to about $75 \%$ of that of controls after 52 days, and providing about 20\% of long-term survivors [76].

\section{Fludarabine (FAMP; 11a)}

Fludarabine (arabinofuranosyl-2-fluoroadenine mono phosphate), has also been studied as a possible prodrug 

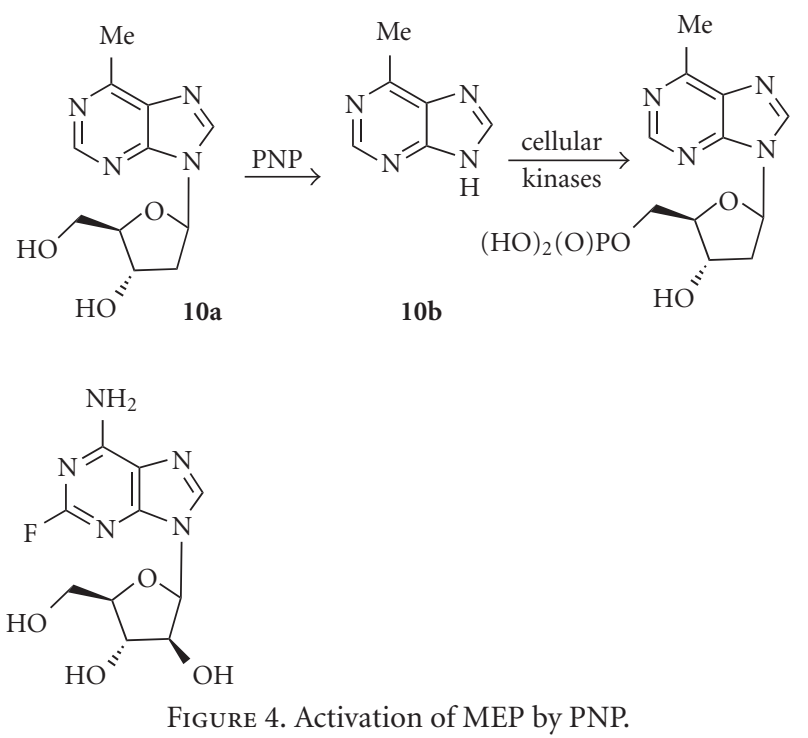

for PNP gene therapy. FAMP showed good activity against sc D54MG glioma tumor xenografts expressing E. coli PNP, but was not quite as effective as MEP [77]. Human hepatocellular carcinoma cell lines (HepG2, Hep3B, and HuH-7) expressing PNP were highly sensitized to FAMP, showing $\mathrm{IC}_{50} \mathrm{~s}$ of $<1 \mu \mathrm{mol}$, with excellent bystander effects (better than those for GCV) [78]. Treatment of PNP-transduced HepG2 and Hep3B cells with FAMP induced p53 accumulation and the rapid onset of apoptosis, and caused similar levels of killing in both p53-positive and negative lines. This independence of FAMP-induced killing on p53 status suggests that FAMP/PNP may be superior to GCV/HSV-Tk for gene therapy of human hepatocellular carcinoma [79].

\section{PRODRUGS FOR CYP ENZYMES}

\section{Introduction}

Prodrugs for gene therapy based on NADH cytochrome P450 (CYP) enzymes are compounds that are normally activated primarily by one or more of the many CYP isozymes [80]. The large number of different isozymes, and the fact that many drugs and other xenobiotics are metabolized by them, makes the potential choice of prodrugs quite wide. Many of these enzymes are expressed to greater extent in liver than in tumor cells, so the primary goal of this strategy is to selectively increase tumor cell exposure to cytotoxic drug metabolites by targeting expression of the enzymes to tumor cells by gene vectors. To date, this area has been dominated by only two prodrugs, the alkylating agents cyclophosphamide and ifosfamide, but the range of potential compounds is expanding.

\section{Cyclophosphamide (CPA; 12a)}

This is the most widely used alkylating agent in conventional cancer chemotherapy. It is much more lipophilic than the majority of the antimetabolites discussed above $(\log \mathrm{P}+0.23)$ and works by a different mechanism. It is converted to the active alkylating agent phosphoramide mustard (12b) via initial hydroxylation to 4-hydroxycyclophosphamide (hydroxy-CPA) by CYP enzymes (primarily CYP2B1) in the liver (tumor cells generally contain only low levels of enzyme). HydroxyCPA is in equilibrium with the open-chain aldophosphamide, which undergoes spontaneous elimination to give acrolein and phosphoramide mustard (Figure 5a). Phosphoramide mustard is a DNA cross-linking agent that kills cells in a largely cell cycle-independent manner, and thus CPA has potential advantages over GCV and 5-FC, which are cell cycle-specific agents. While phosphoramide mustard itself is very polar $\left(\log D_{7}-3.95\right)$, the more lipophilic intermediate CPA metabolites (primarily hydroxy-CPA) do not require cell-cell contact for a bystander effect, distributing by passive diffusion $[81,82]$. Early studies with CPA in gene therapy utilized both retroviral- and adenoviral-mediated transduction of glioma cells with CYP2B1, and showed that this sensitized them to CPA both in vitro [83] and in vivo [81]. Protection of transduced cells from CPA-induced cytotoxicity with the CYP2B1 enzyme inhibitor metyrapone showed that this sensitization was a direct consequence of intracellular prodrug activation [81]. Since CYP-catalyzed drug metabolism is dependent on electron transfer from the flavoenzyme NADPH-P450 reductase, double transduction of rat 9L glioma cells with both enzymes substantially increased tumor cell killing [84], and inhibitors of NADPH-P450 reductase inhibited the activation of CPA by CYP enzymes $[85,86]$.

The use of other CYP isozymes to activate CPA has been explored. AHH-1 human lymphoblastoid cells transfected with CYP2C9 were 5-fold sensitized to CPA compared with the wild-type line $\left(\mathrm{IC}_{50} \mathrm{~s} 0.80\right.$ and $4.1 \mathrm{mmol}$, respectively), and showed a bystander killing effect. This sensitivity was blocked by the CYP2C9specific inhibitor sulfaphenazole. While the sensitivity enhancement is not large, CYP2C9 and CPA may possibly be useful for GDEPT [87]. In a comparative study, 9Lrat glioma cells were transfected with six different CYP enzymes; 2B6, 2C8, 2C9, 2C18 (Met385 and Thr385 alleles), 2C19, and 3A4 [88]. Greatest sensitization to CPA was seen with CYP2B6, but CYP2C18-Met was also effective, despite a very low level of CYP protein expression (> 60-fold lower than that of 2B6), with substantial further increases upon additional transduction with $\mathrm{NADH}$ P450 reductase. In 9L glioma sc tumors transduced with $2 \mathrm{~B} 6$ or $2 \mathrm{C} 18-\mathrm{Met}$ in immunodeficient mice, the best effects were seen with concomitant expression of NADH P450 reductase (growth delays of 25-50 days, compared with 5-6 days). Transduction of HT29 and T47D human colon carcinoma cells with CYP2B6 using a retroviral vector (MetXia-P450) sensitized these cells to CPA, and produced a substantial bystander effect in 3-D multicellular spheroid models [89]. Treatment of scid mice bearing $400 \mathrm{~mm}^{3} \mathrm{sc}$ tumors from 9L glioma cells transduced with 


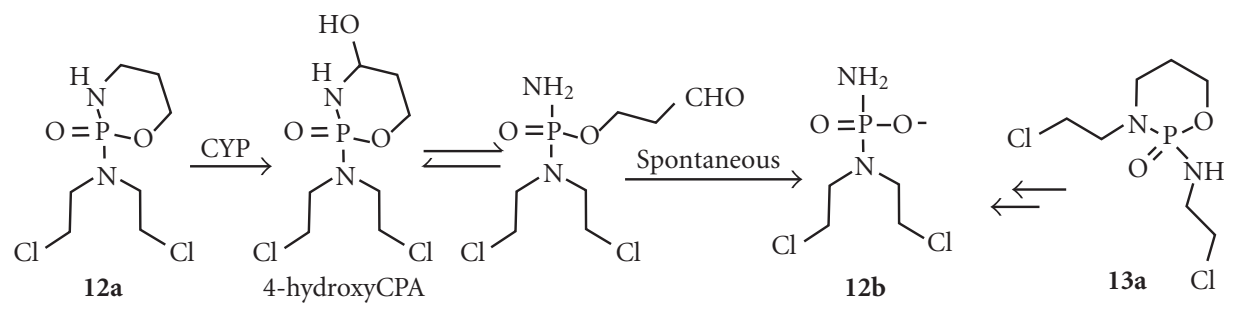

(a)
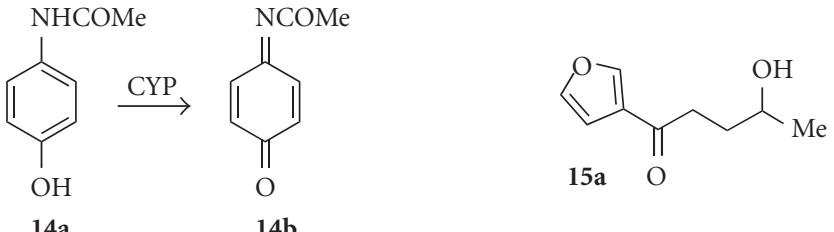

(b)

FIgURE 5. (a) Activation of cyclophosphamide and ifosfamide of CYP. (b) Activation of acetaminophen by CYP.

CYP2B6 and NADHP450 reductase with CPA $(140 \mathrm{mg} / \mathrm{kg}$ every 6 days) achieved eradication of 6 out of 8 tumors. With larger tumors, some resistance to CPA was seen, involving loss of expression of the genes [90].

\section{Ifosfamide (IFO; 13a)}

Ifosfamide is also used clinically as a conventional anticancer drug. It is closely related both chemically and mechanistically to cyclophosphamide, having similar lipophilicity $(\log \mathrm{P}+0.50)$ and releasing the same ultimate metabolite, phosphoramide mustard (12b) (Figure 5a). Feline kidney cells transfected with CYP2B1 were sensitized to IFO, and killed via necrotic rather than apoptotic mechanisms [91]. When these cells also expressed cytosine deaminase, additive killing was seen with combinations of both IFO and 5-FU [92]. CYP2B1-transduced human embryonic epithelial cells implanted in mice bearing human $\mathrm{PaCa}-44$ pancreatic tumor xenografts sensitized these to IP IFO, resulting in partial or even complete tumor ablation [93]. 9L glioma cells transduced with CYP2B6 and NADPH P450 reductase were sensitized to both CPA and the bioreductive drug tirapazamine (TPZ) to the same extent under both normoxic $\left(20 \% \mathrm{O}_{2}\right)$ and hypoxic $\left(1 \% \mathrm{O}_{2}\right)$ conditions [94]. Under hypoxia, both CPA and TPZ showed bystander effects, which is surprizingly given the nature of the highly reactive radical intermediate thought to be the active species of TPZ.

\section{Acetaminophen (14a)}

The widely used and relatively lipophilic $(\log \mathrm{P}+0.34)$ anti-inflammatory drug acetaminophen is oxidized by the human CYP1A2 enzyme to the cytotoxic metabolite
$\mathrm{N}$-acetylbenzoquinoneimine (NABQI; 14b) (Figure 5b), which is the major source of toxicity of this drug. Transfection of H1A2 MZ cells with human CYP1A2 sensitized them to treatment with acetaminophen, with the generation of a substantial bystander effect (complete killing of V79 cells in a mixture containing 5\% transduced H1A2 MZ cells) [95]. Similar bystander effects were seen with transduced SK-OV-3 human ovarian tumor cells and HCT116 human colon tumor cells, but not with MDAMB-361 breast tumor cells. Acetaminophen is thus a possible prodrug for GDEPT in conjunction with CYP1A2.

\section{4-Ipomeanol (4-IM; 15a)}

4-Ipomeanol is a relatively lipophilic furoketone $(\log \mathrm{P}+0.70)$ that is efficiently converted by the rabbit CYP4B1 enzyme, but not by the corresponding human isozyme, into toxic DNA-alkylating metabolites of unreported structure [96]. Both rat (9L) and human (U87) glioma cell lines transduced with rabbit CYP4B1 were sensitized about 20 fold to 4 -IM ( $\mathrm{IC}_{50} \mathrm{~s}$ about $2.5 \mu \mathrm{mol}$ ), with an efficient bystander effect. Cell killing was associated with DNA fragmentation (TUNEL assays) and extensive protein-DNA crosslinking and single-strand breaks. In 9L sc tumor xenografts in nude mice, 4-IM induced significant growth delays. Similar results were seen in a range of human hepatocellular carcinoma cell lines (Hep3B, $\mathrm{HuH}-7$, and HepG2) transduced with rabbit CYP4B1 and treated with 4-IM, except that bystander effects seemed to be cell-specific [97]. In a further comparative study [98], 4-IM treatment of CYP4B1-transduced 9L glioma cells showed very little bystander effect (much less than that shown by GVC/HSV-Tk). Thus the utility of 4-IM for GDEPT needs further clarification. 

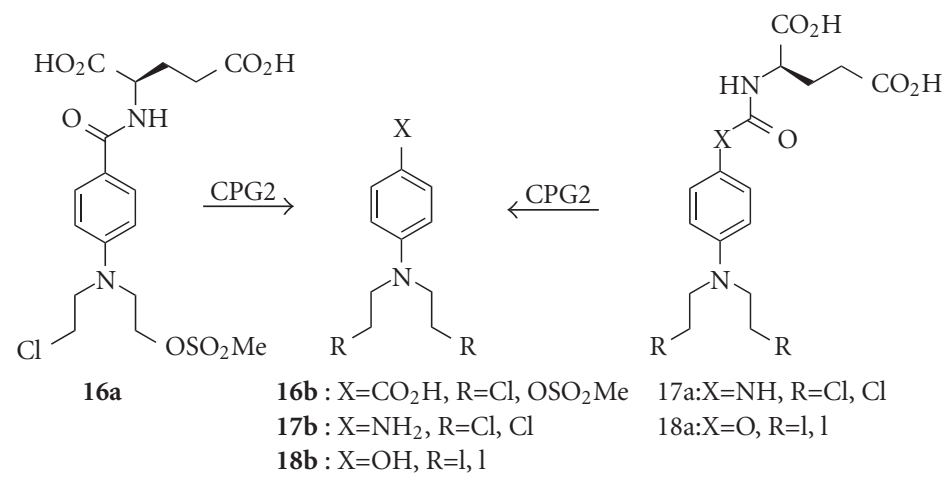

(a)

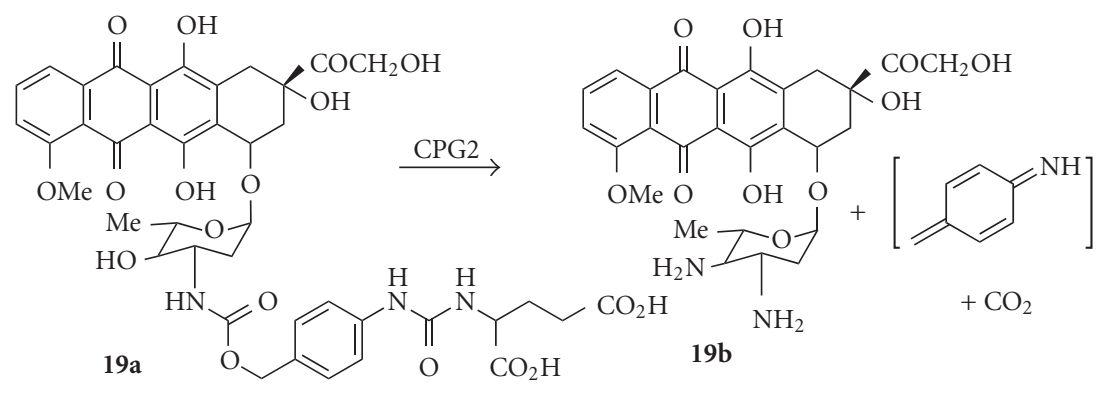

(b)<smiles>CN(Cc1cnc2nc(N)nc(N)c2n1)c1ccc(C(=O)NCCC(=O)N[C@@H](Cc2ccccc2)C(=O)N[C@@H](CCC(=O)O)Cc2ccc(N(C)c3ccc(C(=O)N[C@@H](CCC(=O)O)C(=O)O)cc3)cc2)cc1</smiles>

(c)

Figure 6. (a) Activation of mustards by CPG2. (b) Activation of anthracycline glutamates by CPG2. (c) Activation of methotrexate$\alpha$-peptides by CPGA.

\section{PRODRUGS FOR CARBOXYPEPTIDASES (CP)}

\section{Introduction}

This enzyme, from various species of Pseudomonas bacteria, and for which there is no mammalian counterpart, has been investigated for use in gene therapy because of its ability to cleave glutamate moieties [99]. Because the substrates for this enzyme are necessarily diacids, it has been used primarily in ADEPT protocols, where cell exclusion of very polar prodrugs until activation is an added benefit. However, more recently it has been adapted for use in GDEPT by being engineered for surface expression on the cells [100].

\section{4-[(2-chloroethyl)(2-mesyloxyethyl)amino]benzoyl- L-glutamic acid (CMDA; 16a)}

The very polar $\left(\log \mathrm{D}_{7}-4.67\right)$ "mixed" chloromesylate mustard CMDA was first studied as a prodrug for ADEPT, in conjunction with the enzyme carboxypeptidase G2 (CPG2) derived from the bacterium Pseudomonas putida, which cleaves the glutamate to generate the active carboxylic acid species 16b (Figure 6a) [99]. However, studies with human adenocarcinoma cell lines (A2780 and SK-OV-3) and human colon carcinoma cell lines (LS174T and WiDr) that expressed CPG2 internally showed enhanced sensitivity to CMDA over control lines (11-16 fold for WiDr and SK-OV-3, 95 fold for A2780 and LS174T), 
showing these diacids do enter cells [100]. Complete cell killing was achieved with $4-12 \%$ of cells expressing the enzyme, indicating a substantial bystander effect from the much more lipophilic $(\log \mathrm{P}+0.05)$ released aniline mustard effector 16b. Nevertheless, later work comparing CMDA with internally-expressed and surface-tethered CPG2 enzymes in the A2780, SK-OV-3, and WiDr cell lines showed the latter was superior for activating CMDA [101]. Lower levels of enzyme and shorter exposures to prodrug were required for cell killing with surfacetethered compared to internally-expressed CPG2. The activity of CMDA against human MDA-MB-361 breast carcinoma xenografts in nude mice correlated with the percentage of CPG2-expressing cells, with some cures seen even with tumors containing 50\% wild-type cells, confirming a substantial bystander effect [102].

\section{Hydroxy-and amino-aniline mustards (eg, 17a and 18a)}

Because the effector $\mathbf{1 6 b}$ released from CMDA is only a moderately potent cytotoxin (IC $5065 \mu \mathrm{m}$ in LS174T human colon carcinoma cells [103]), more potent effectors have been sought. Thus the prodrugs $17 \mathbf{a}$ and $18 \mathrm{a}$ release effectors (17b and 18b; Figure 6a) that are up to 70 -fold more potent than 16b $\left(\mathrm{IC}_{50} \mathrm{~s}\right.$ in LoVo colon carcinoma cells of $1.8 \mu \mathrm{mol}$ and $0.34 \mu \mathrm{mol}$, respectively) [103, 104]. These prodrugs showed $\mathrm{IC}_{50}$ differentials of $12-14$ fold between wild-type and surface CPG2-expressing WiDr human colon tumor cell lines in culture. The iodomustard glutamate prodrug 18a, already in clinical trial as a prodrug for ADEPT [105], also showed much greater $\mathrm{IC}_{50}$ differentials in surface CPG2-expressing MDA-MB361 and WiDr cells than did CMDA (70-450 fold compared to 19-27 fold), and was highly effective against the MDA-MB-361 xenografts in nude mice [106].

\section{Anthracycline glutamates}

Prodrugs of anthracycline topoisomerase inhibitors such as doxorubin with glutamate residues directly attached to the glycoside nitrogen were not substrates for CPG2, so analogues with a 4-benzylcarbamate spacer group were investigated [107]. These prodrugs (eg, 19a) undergo 1,6-elimination following cleavage of the glutamate by CPG2 to release doxorubicin (19b) (Figure 6b). MDA-MB-361 breast cancer cell lines expressing CPG2 intracellularly or tethered to the outer cell membrane showed about a 10 -fold $\mathrm{IC}_{50}$ differential compared to wild-type cells [107].

\section{Methotrexate $\alpha$-peptides (MTX-Phe; 20a)}

Methotrexate- $\alpha$-peptides (eg, MTX-Phe; 20a) are prodrugs of methotrexate (MTX; 20b), a potent inhibitor of dihydrofolate reductase, and a widely used anticancer drug. Unlike MTX, the prodrugs are poor substrates for the reduced folate carrier, and thus not taken up by cells, but can be cleaved to methotrexate by carboxypeptidase A1 (CPGA) (Figure 6c) [108]. This endogenous enzyme is normally inactive until trypsin proteolysis of its propeptide, but a mutant form (CPAST3), activated by ubiquitously expressed intracellular propeptidases, has similar prodrug activating properties [109]. Tumor cells retrovirally transfected with a cell surface tethered version of CPAST3 were highly sensitized to MTX-Phe, which also showed an efficient bystander effect (complete cell kill with $<10 \%$ of the cells transduced).

\section{PRODRUGS FOR CARBOXYLESTERASE (CE)}

\section{Introduction}

The group of enzymes known as carboxylesterases hydrolyse esters and some carbamates to their component acids and alcohols, and are known to activate some clinical anticancer drugs, notably irinotecan [110] and KW2189 [111].

\section{Irinotecan (IRT; 21a)}

Irinotecan is a lipophilic $\left(\log \mathrm{D}_{7}=1.54\right)$ topo I inhibitor that has been used widely clinically as an anticancer drug. It is converted to the active form SN-38 (7ethyl-10-hydroxycamptothecin, 21b) in humans primarily by carboxylesterase (Figure 7a). However, human CE is relatively poor at activating IRT, with rabbit liver CE being 100-1000-fold more efficient [110]. A 549 human lung adenocarcinoma cells transfected with the human carboxylesterase gene driven by the CMV promoter were able to convert IRT to the active metabolite SN-38, which showed a substantial bystander effect in cell culture [112]. When the construct was injected directly into established sc A549 tumors in nude mice, treatment with IRT resulted in $30-40 \%$ reductions in tumor size compared with controls. A panel of human tumor cell lines transduced with rabbit liver CE showed high levels of CE activity, and were sensitized by 11-127 fold to IRT [110]. This protocol has been studied as a potential purging method in autologous stem cell rescue for neuroblastoma. Transfection of neuroblastoma cell lines (SJNB-1, NB-1691, and SK-N-SH) by a replication-deficient adenoviral construct containing rabbit CE resulted in $100 \%$ transfection, and sensitized the cells to IRT by $20-50$ fold [113].

\section{Anthracycline acetals (22a)}

The lipophilic doxorubicin acetal (22a) $\left(\log \mathrm{D}_{7}+2.04\right)$ is a substrate for CE, which hydrolyses it to an intermediate hemiacetal that undergoes immediate cyclization to the cyclic carbinolamine (22b) (Figure 7b) [114]. These anthracycline carbinolamines (or more likely the resultant iminium ion; Figure 7b) are known to be extremely cytotoxic agents (100-1000-fold more potent than doxorubicin itself), probably due to covalent interaction with DNA. However, the system does not appear to have been evaluated in CE-transfected cell lines, and it is likely that compounds like 22a are too unstable to act as tumorspecific prodrugs. 


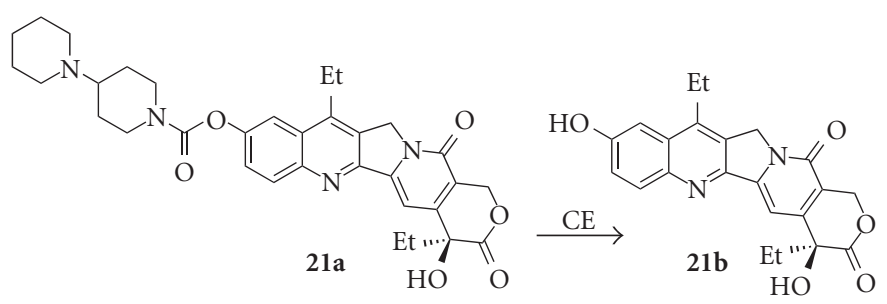

(a)

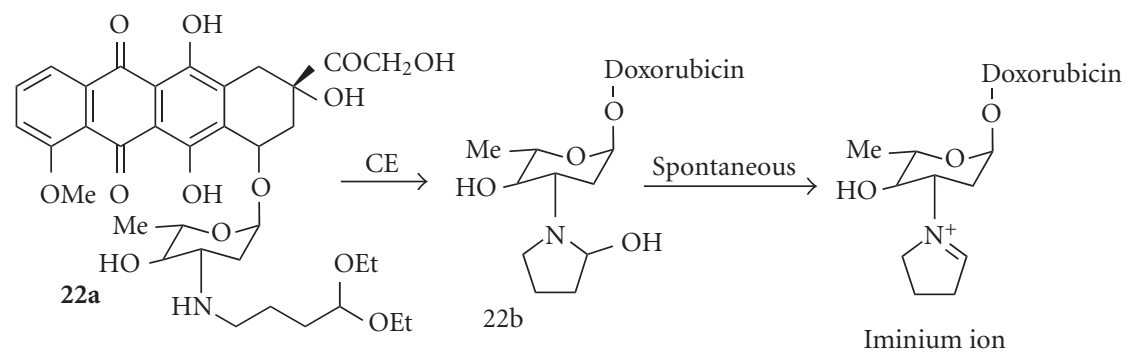

(b)

FIgUre 7. (a) Activation of irinotecan by CE. (b) Activation of doxorubicin acetal by CE.

\section{PRODRUGS FOR NITROREDUCTASE (NTR)}

\section{Introduction}

Enzymes that metabolize aromatic nitro groups are attractive for GDEPT because of the very large electronic change that this metabolism generates. Metabolism of a nitro group (Hammett $\sigma_{p}$ electronic parameter $=0.78$ ) to the corresponding hydroxylamine 4-electron reduction product $\left(\sigma_{p}=-0.34\right)$ that is normally the major metabolite, or the possible amine 6 -electron reduction product $\left(\sigma_{p}=-0.66\right)$ (Figure 1). These are among the largest possible increases in the electronic effect $(\Delta \sigma=1.12$ and 1.44) that can be achieved in a single metabolic step [115], and this substantial change in electron distribution in the prodrug can be exploited in a variety of ways to activate the effector. Nearly, all GDEPT studies with nitroreductases have used the nfsB gene product of $E$. coli, an oxygeninsensitive flavin mononucleotide (FMN)-containing nitroreductase (NTR) [116], with a close sequence homology to the classical nitroreductase of S. typhimurium [117]. Crystal structure determinations of NTR show it to be a homodimer with one FMN per monomer, with two channels leading into the active site [118]. There are relatively few contacts made with the ligand, which may contribute to its observed broad substrate specificity [119]. NTR efficiently reduces aromatic nitro groups to the hydroxylamines in a two-step ping pong bi-bi mechanism [118]. Four broad classes of prodrugs for NTR have been studied; dinitroaziridinylbenzamides, dinitrobenzamide mustards, 4-nitrobenzylcarbamates, and nitroindolines, and most work has been done with the dinitroaziridinylbenzamide CB1954.

\section{CB1954 (23a)}

The dinitroaziridinylbenzamide CB1954 (23a) is a relatively lipophilic $(\log \mathrm{P}+1.54)$ prodrug that is efficiently reduced by NTR $\left(\mathrm{k}_{\mathrm{cat}}=360 \mathrm{~min}^{-1}\right)$ [117], effecting reduction of either the 4- or 2-nitro groups to the corresponding hydroxylamines at about equal rates (Figure 8a). Modelling suggests that the small aziridine residue allows the drug far enough into the binding pocket that both the 2and 4-nitro groups have access to the FMN [118]. The 4hydroxylamine (23b) is then further metabolized by cellular acetylation pathways to a cytotoxic DNA interstrandcrosslinking agent [120] (Figure 8a). CB1954 demonstrates substantial bystander effects [121], due to the cellpermeable hydroxylamine metabolite $(\log \mathrm{P}-0.34)[122]$. CB1954 shows high selectivity (100-2000 fold) in a variety of NTR-transfected cell lines, including human ovarian (SKOV-3) [123], colorectal (LS174T), and pancreatic (SUIT2, BxPC3) [124], with sensitivity correlating closely with the level of NTR enzyme expression [123].

B1954 also showed excellent bystander effects in vivo, inducing long growth delays of human hepatocellular carcinoma and squamous carcinoma xenografts, even when only a minority of the tumor cells expressed the enzyme [125]. Treatment of scid mice with Burkitt lymphoma (Jijoye) tumors containing 30\% NTR-expressing cells with CB1954 at $20 \mathrm{mg} / \mathrm{kg} /$ day for 10 days also gave growth inhibition, suggesting a substantial bystander effect [126]. However, expression of NTR in the luminal cells of the mammary gland using the ovine $\beta$-lactoglobulin promoter resulted in rapid and selective killing of this cell population by CB1954 with minimal effects 


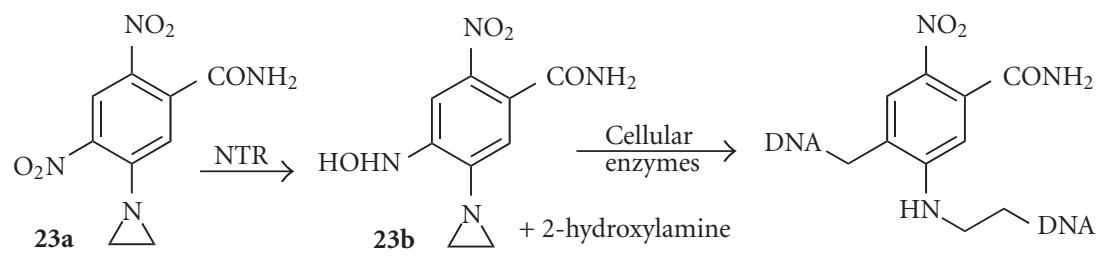

(a)<smiles>NC(=O)c1cc(N(CCCl)CCCl)c(NOc2cc([N+](=O)[O-])c(N(CCCl)CCCl)cc2N(CCCl)c2cc(C(N)=O)c(N(CCCl)CCCl)cc2[N+](=O)[O-])cc1N</smiles><smiles>NC(=O)c1cc([N+](=O)[O-])cc([N+](=O)[O-])c1N(CCCl)CCCl</smiles>

(b)

Figure 8. (a) Activation of CB1954 by NTR. (b) Activation of SN23862 by NTR.

neighbouring myoepithelial cells, suggesting that the toxic metabolite does have a finite diffusion range [127].

A Phase I clinical trial of CB1954 without NTR, administered IV on a 3-weekly cycle, determined a recommended IV dose of $24 \mathrm{mg} / \mathrm{m}^{2}$. Dose-limiting toxicities at $37.5 \mathrm{mg} / \mathrm{m}^{2}$ were diarrhoea and elevation of liver transaminases, but no marrow suppression or nephrotoxicity. A Phase I clinical trial of CB1954 in combination with adenovirus-delivered NTR is in progress in patients with primary and secondary liver cancer [128].

\section{SN23862 (24a) and analogues}

The dinitrobenzamide mustard SN23862 is more lipophilic than CB1954 $(\log \mathrm{P}=2.06)$, and a better substrate for NTR $\left(\mathrm{K}_{\mathrm{cat}} 1580 \mathrm{~min}^{-1}\right)$ [129]. Unlike CB1954, only the 2-nitro group is reduced (possibly because the larger mustard unit restricts drug entry to the active site of NTR) to give the lipophilic $(\log \mathrm{P}=2.50) 2$ hydroxylamine (24b) (Figure 8b) [130]. The initial reductive step fully activates the mustard for DNA crosslinking without further metabolism. While mammalian enzymes with nitoreductase activities exist, in rats, the major endogenous reductive pathway is via the 4-nitro group, giving the 4-hydroxylamine (25) and ultimately the relatively nonpotent tetrahydroquinoxaline (26) as the major metabolite (Figure 8b) [131]. SN23862 [132] and other mustard analogues [133] are also not substrates for endogenous DT diaphorase, increasing their attractiveness as NTR prodrugs.

A recent study [4] of a series of analogues of 23a and 24a demonstrated good correlations between the lipophilicities of the parent prodrugs (measured $\log \mathrm{P}$ values) and their bystander effects, measured in both 3-D cell multilayer cocultures of NTR+ve and NTR-ve V79 and WiDR cells, and also in mixed NTR+ve/NTR-ve WiDr tumors in nude mice. This study provides quantitative evidence, in a series of close analogues, of the importance of lipophilicity in determining the level of bystander effect; analogues with $\log \mathrm{P}$ values lower than that of CB1954 showed relatively poor bystander effects.

In a series of analogues of SN23862 where the 4nitro group was replaced by other substituents of varying electronic properties, cytotoxicity in UV4 cell cultures, from added NTR enzyme, correlated roughly with the electron-withdrawing properties of the 4-substituent [134]. The 2-amino-3, 5-dinitrobenzamide regioisomer (27a) of SN23862 was also a substrate for NTR, and was in fact superior, with a $\mathrm{k}_{\mathrm{cat}}$ of $4540 \mathrm{~min}^{-1}$ [129]. Comparative cell line studies with SN23862 and the regioisomers 27a and 28a in NTR-transfected Chinese hamster-derived 


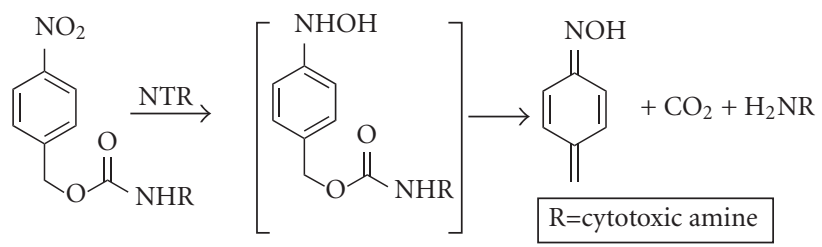

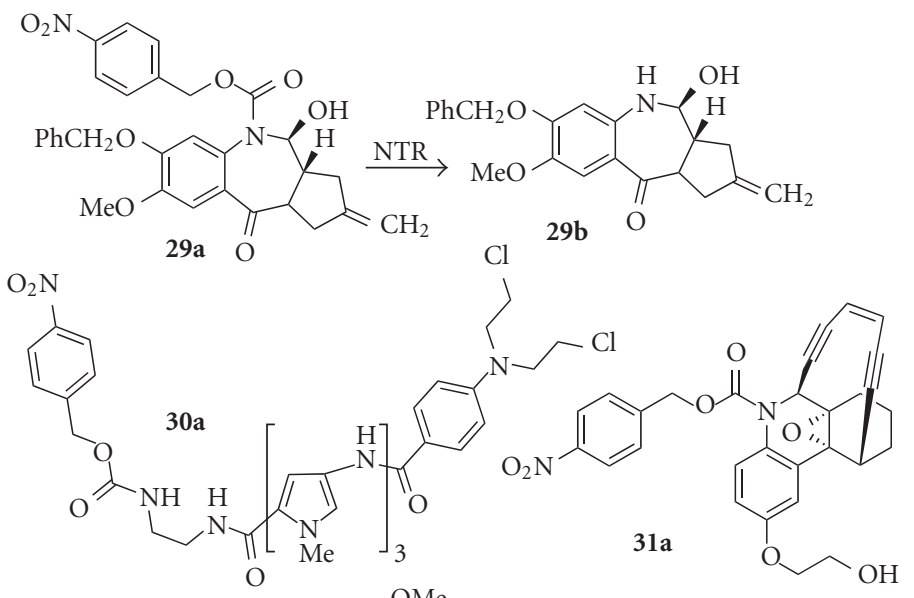<smiles></smiles><smiles>CCOC(=O)NC1=C(N2CC2)C(=O)C(NC=O)=C(N2CC2)C1=O</smiles>

FIGURE 9. Activation of 4-nitrobenzyl carbamates by NTR.

cell lines showed that regioisomeric changes are permitted, with the all three retaining selective cytotoxicity. Finally, analogues with other leaving groups (bromoand iodo-mustards) retain good selectivity for the NTRtransfected line together with higher potency [135].

\section{4-Nitrobenzyl carbamates}

Despite their low reduction potential of around -490 mV [136], 4-nitrobenzyl carbamates are substrates for NTR, being reduced to the hydroxylamines which then undergo spontaneous fragmentation to release an aminebased effector (Figure 9) [137]. Electron-donating substituents on the benzyl ring accelerate the fragmentation step [138]. This system is theoretically very flexible, and 4nitrobenzyl carbamates of a number of different classes of cytotoxic amines have been explored as potential GDEPT prodrugs [139].

4-Nitrobenzyl carbamate prodrugs (29a, 30a) of DNA major groove alkylating pyrrolo[2,1-c] benzodiazepines (29b) [140], and of DNA minor groove alkylating tallimustine mustards (30b) [141] showed differential cytotoxicity towards cells in culture when cotreated with NTR plus cofactor NADH, but studies have not been reported in NTR-transfected cell lines. The enediyne prodrug (31a) showed moderately selective cytotoxicity (135 fold) in the NTR-transfected WiDr human colon carcinoma cell line [142]. Nitroheterocyclic carbamate trigger units have also been reported. The 2-nitroimidazole carbamate prodrug (32a) of an amino-duocarmycin effector (32b) was 20-fold more toxic to NTR-transfected SKOV-3 human ovarian carcinoma cell line over the wild-type [143], extending the types of trigger units that can be used for this purpose.

\section{Quinones}

Quinones can be excellent substrates for NTR (the $\mathrm{k}_{\mathrm{cat}}$ for menadione is $4.2 \times 10^{4} \mathrm{~min}^{-1}$ compared with $360 \mathrm{~min}^{-1}$ for CB1954) [117], but this is not universal; mitomycin 


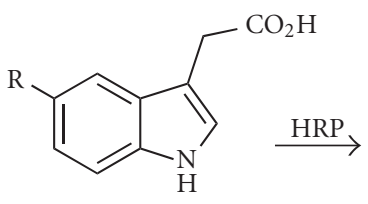

$35 \mathrm{a}: \mathrm{R}=\mathrm{H}$ 36a $: \mathrm{R}=\mathrm{F}$

Figure 10. Activation of IAA and FIAA by HRP.<smiles>[R]c1ccc2c(c1)C(=C)C(=O)N2</smiles>

$35 b: \mathrm{R}=\mathrm{H}$ $36 \mathrm{~b}: \mathrm{R}=\mathrm{F}$
$\mathrm{C}$ is a poor substrate [129]. The quinones EO9 (33a) and AZQ (34a) (Figure 10) generate DNA-reactive species when reduced, but were less than three-fold more cytotoxic in NTR-transfected V79 cells compared to wild-type cells [144].

\section{PRODRUGS FOR HORSE-RADISH PEROXIDASE (HRP)}

\section{Introduction}

HRP is an iron-containing heme peroxidase that is well known to oxidize a variety of phenols and amines, including indole-3-acetic acid, without requiring added hydrogen peroxide as a cofactor. The mechanism of oxidation by HRP has been widely studied, and shown to involve a series of free radical intermediates of varying iron oxidation levels [145].

\section{Indole-3-acetic acid (IAA; 35a)}

Indole-3-acetic acid, a catabolite of tryptophan and a plant growth hormone, is relatively nontoxic to mammalian cells. It is oxidized by HRP, initially to a nitrogencentred radical-cation species that rapidly fragments via a carbon-centred benzyl radical. However, both of these radical species are extremely short-lived, and unlikely to account for the observed bystander effects of IAA. The 3-methylene-2-oxindole (35b) (Figure 10), derived from the hydroperoxide of the benzyl radical by an unclear pathway, has been suggested as the active diffusing species, able to react with DNA [145]. This is sufficiently long-lived to generate a bystander effect, and sufficiently lipophilic $(\log \mathrm{P}+1.35)$ to diffuse rapidly by passive diffusion [146]. HRP transfection effectively sensitized human T24 bladder carcinoma cells to IAA under both normoxic and anoxic conditions. IAA also elicted a significant, selective enhancement of radiation-mediated cytotoxicity in T24 cells transiently transfected with the HRP, showing sensitizer enhancement ratios (SER) ranging from 2.6 to 5.4 [147].

\section{5-Fluoroindole-3-acetic acid (FIAA; 36a)}

This prodrug is related to IAA, and despite being less rapidly oxidized by HRP to the corresponding effector (36b) (rate constant $3.8 \times 10^{2} \mathrm{~mol}^{-1} \mathrm{sec}^{-1}$ compared to $3.8 \times 10^{3} \mathrm{~mol}^{-1} \mathrm{sec}^{-1}$ for IAA) is more cytotoxic than IAA in a range of HRP-transfected human and rodent tumor cell lines [148]. Plasma levels of $1 \mathrm{mmol}$ and tumor levels of

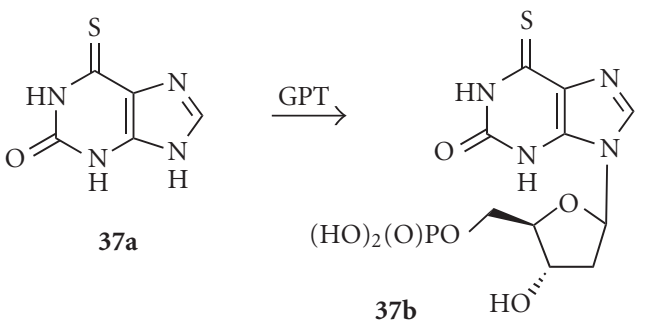

FIgURE 11. Activation of 6-thioxanthine by GPT.

$200 \mu \mathrm{mol}$ of FIAA were seen in mice bearing murine carcinoma NT tumors, after IP administration of $50 \mathrm{mg} / \mathrm{kg}$ FIAA.

\section{PRODRUGS FOR GUANINE RIBOSYLTRANSFERASE (XGRPT)}

\section{Introduction}

The E. coligpt gene encodes a xanthine-guanine phosphoribosyl transferase (XGRPT) that has various xanthine and guanine analogues as substrates [149].

\section{6-Thioxanthine (6-TX; 37a)}

6-Thioxanthine (37a) is a relatively nontoxic compound (it is a catabolite of the clinically used antimetabolite 6-thioguanine), and is a substrate for E. coli XGRPT, being converted to the toxic ribophosphate (37b) (Figure 11). Rat C6 glioma cells retrovirally transduced with E. coli XGRPT were more than 20 -fold sensitized to 6-TX ( $\mathrm{IC}_{50}$ of $2.5 \mu \mathrm{mol}$ compared to $>50 \mu \mathrm{mol}$ ) [149]. It showed only a weak bystander effect in mixed cocultures [150], which is not unexpected in view of the very hydrophilic $\left(\log D_{7}-5.52\right)$, charged nature of the phosphorylated active species $\mathbf{3 7} \mathbf{b}$. The prodrug was moderately active in intracerebral C6 glioma xenografts in nude mice, with an $80 \%$ reduction in intracerebral tumor volume and a $28 \%$ increase in mean survival, following intratumoral injection of 6-TX [150].

\section{PRODRUGS FOR GLYCOSIDASE ENZYMES}

\section{Introduction}

Glycosidase enzymes have been used mostly in ADEPT, because their very hydrophilic sugar-bearing substrates show slow cell uptake. However, as with the case of the CPG2 enzyme, studies with secreted forms of $\beta$ glucuronidase and $\beta$-galactosidase show that these enzymes can also be used for GDEPT, in conjunction with anthracycline-based prodrugs. Both human and E. coli enzymes have been used.

\section{$H M 1826(38 a)$}

OVCAR-3 cells transfected (using a cationic lipid transfecting agent) with plasmids encoding E. coli- or human $\beta$-glucuronidase were equally sensitized to both the 

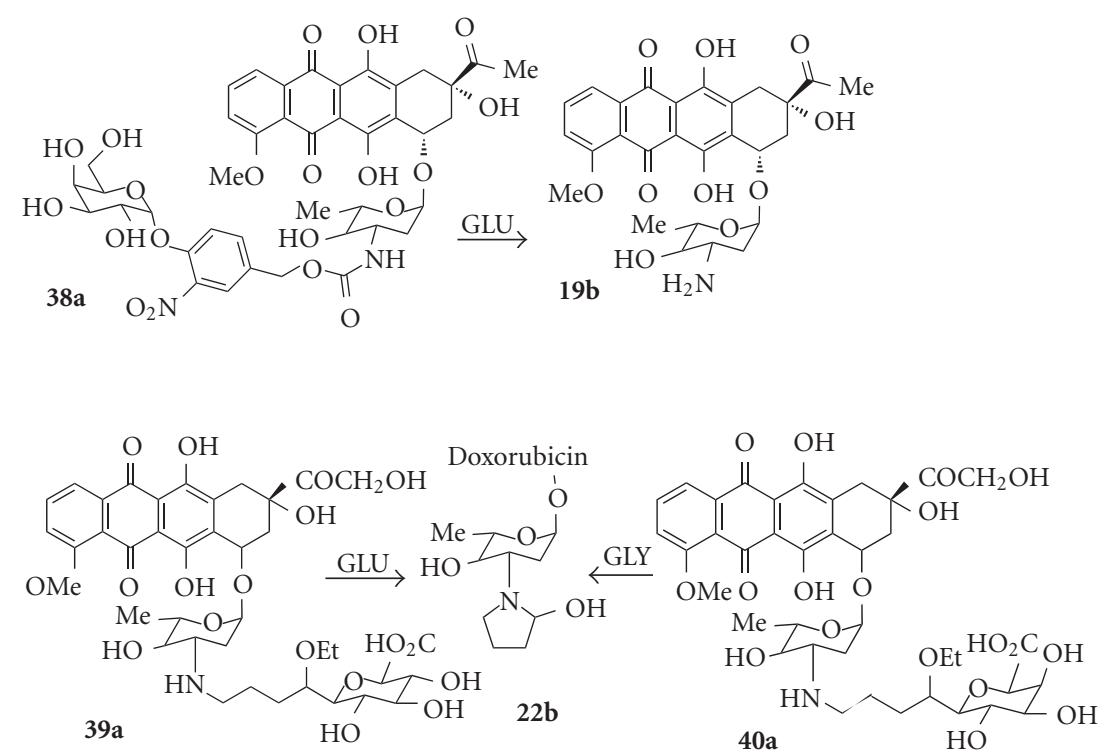

Figure 12. Activation of anthracycline by glycosidases.

glucuronide prodrug DOX-GA3 and the effector doxorubicin produced from it (Figure 12), suggesting good uptake and conversion of the prodrug, but the bacterial enzyme was more efficient. Studies with mixed cell cultures showed a strong bystander effect [151]. However, most work has been done using secreted [152] or surfacetethered [153] forms of the enzymes, with prodrugs such as HMR1826 (38a). Despite the high DNA binding of the released doxorubicin effector $19 b$, moderate to good bystander effects were reported in culture and in vivo.

\section{Anthracycline acetals}

As noted in "Anthracycline acetals", anthracycline carbinolamines such as $\mathbf{2 2 b}$ are extremely potent cytotoxins, probably because of their spontaneous conversion to iminium ions that can alkylate DNA. The glucuronide and galactosyl prodrugs (39a and 40a, respectively) are substrates for $E$. coli $\beta$-glucuronidase and $\beta$ galactosidase, from which that release the carbinolamine 22b (see Figure 7). In cell culture they were about $10^{4}$ and $10^{6}$-fold more toxic respectively to human A375 melanoma cells in the presence of the enzymes [154, 155] (see also "Anthracycline acetals"). While this is only a simple assay (the activating enzymes would need to be surface-tethered in a GDEPT application because of the very hydrophilic prodrugs), the very large differential cytotoxicity is noteworthy.

\section{PRODRUGS FOR THYMIDINE PHOSPHORYLASE (TP)}

\section{Introduction}

The endogenous enzyme thymidine phosphorylase (TP), which is reported to occur to a greater extent in tumor cells than in normal tissue, is a monomeric 55-kd enzyme that dephosphorylates thymidine and

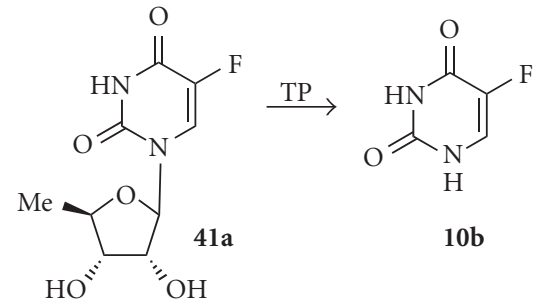

Figure 13. Activation of 5'-DFUR by TP.

related pyrimidine antimetabolites such as $5^{\prime}$-deoxy-5fluorouridine [156].

\section{5'-Deoxy-5-fluorouridine (5'-DFUR; 41a)}

LS174T human colon carcinoma cells transfected with the human TP gene were up to 40 -fold sensitized to $5^{\prime}$-DFUR, which is converted to 5 -FU (10b) by TP (Figure 13). The degree of sensitization correlated with the extent of expression of TP, and in the cocultures a bystander effect was seen that did not require cell-cell contact [156]. Transfection of PC-9 human lung adenocarcinoma cells with platelet-derived endothelial cell growth factor (identical to human TP) resulted in a 50-fold increase in levels of enzyme expression, and sensitized them to both $5^{\prime}$-DFUR and tegafur [157]. MCF-7 breast cancer cells transfected with the TP had up to 165 -fold increased sensitivity to $5^{\prime}$-DFUR (but not to 5 -FU) in culture, and substantial bystander effects [158].

\section{PRODRUGS FOR METHIONINE- $\alpha, \gamma$-LYASE (MET)}

\section{Introduction}

Many tumors are methionine-dependent, and show elevated levels of methionine synthesis [159]. Thus 


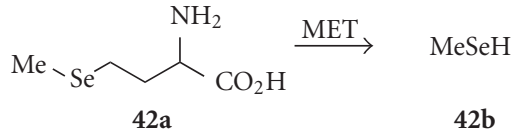

Figure 14. Activation of selenomethionine by MET.

the enzyme methionine- $\alpha, \gamma$-lyase, which degrades the amino acid methionine to ketobutyrate, ammonia, and methylthiol, has been of therapeutic interest, and xenografts expressing the MET gene from Pseudomonas putida grow more slowly than wild-type tumors [160].

\section{Selenomethionine (SeMET; 42a)}

Selenomethionine (SeMET) is a relatively toxic and very polar $\left(\log \mathrm{D}_{7}-3.15\right)$ analogue of the natural amino acid methionine, and is a substrate for MET which converts it to ketobutyrate, ammonia, and the moe lipophilic methylselenol (42b) (Figure 14). Cells transduced by the adenovirus-delivered MET gene from Pseudomonas putida showed up to a 1000-fold increase in sensitivity to SeMET, and showed a strong bystander effect [160]. The enzyme converts SeMET to methylselenol, which damages mitochondria by oxidative stress (production of superoxide and other reactive oxgyen species), resulting in the release of cytochrome $\mathrm{c}$ and activation of the caspase cascade and apoptosis. SeMET inhibited the growth of MET-transfected rat hepatoma N1S1 ascites in nude mice, showing substantial delays in body weight gain due to growth of the tumor ascites [160].

\section{CONCLUSIONS}

There are many issues to be considered in the choice of prodrugs for a particular activating enzyme. While the most obvious are the high turnover by the enzyme and the large differential cytotoxicity between the prodrug and the activated form, another important early consideration was to select compounds (eg, GCV, 5-FU, CPA, IRT) that were already in clinical use. This avoided the regulatory difficulties associated with the combination of a new therapeutic agent and a new activating technology.

Also of importance is the nature of the cytoxicity of the activated drug. Most of the early prodrugs released antimetabolites that act only on cycling cells. However, clinical solid tumors are slow-growing and contain hypoxic regions, resulting in considerable proportions of noncycling tumor cells. This requires prolonged dosing with cell cycle-specific agents to ensure high tumor cell killing. Thus there has been increasing interest ("Prodrugs for CYP enzymes," "Prodrugs for Carboxypeptidases (CP)", and "Prodrugs for Nitroreductase (NTR)" sections) in prodrugs that release DNA cross-linking agents, a class of cytotoxins that are less cell cycle-specific. The potential advantage of these compounds is shown by the fact that single dose protocols can provide curative effects in tumor xenograft models [4].
Later studies have also drawn attention to the importance of the maximizing bystander effects, and this review has focused on the importance of the lipophilicity, charge, and macromolecular binding of both prodrugs and their effectors (Table 1). Suicide gene therapy is a promising but very complex technology, and to be broadly clinically useful will require maximization of the therapeutic properties of all of the components. We are slowly learning how to do this for the prodrugs.

\section{REFERENCES}

[1] Anderson WF. Gene therapy scores against cancer. Nat Med. 2000;6(8):862-863.

[2] Denny WA, Wilson WR, Hay MP. Recent developments in the design of bioreductive drugs. $\mathrm{Br} J$ Cancer Suppl. 1996;27:S32-S38.

[3] Pope IM, Poston GJ, Kinsella AR. The role of the bystander effect in suicide gene therapy. Eur J Cancer. 1997;33(7):1005-1016.

[4] Wilson WR, Pullen SM, Hogg A, Helsby NA, Hicks KO, Denny WA. Quantitation of bystander effects in nitroreductase suicide gene therapy using three-dimensional cell cultures. Cancer Res. 2002;62(5):1425-1432.

[5] De Clercq E. Guanosine analogues as antiherpesvirus agents. Nucleosides Nucleotides Nucleic Acids. 2000;19(10-12):1531-1541.

[6] De Clercq E, Andrei G, Snoeck R, et al. Acyclic/ carbocyclic guanosine analogues as antiherpesvirus agents. Nucleosides Nucleotides Nucleic Acids. 2001;20(4-7):271-285.

[7] Mesnil M, Yamasaki H. Bystander effect in herpes simplex virus-thymidine kinase/ganciclovir cancer gene therapy: role of gap-junctional intercellular communication. Cancer Res. 2000;60(15):39893999.

[8] Steffens S, Frank S, Fischer U, et al. Enhanced green fluorescent protein fusion proteins of herpes simplex virus type 1 thymidine kinase and cytochrome p450 4B1: applications for prodrug-activating gene therapy. Cancer Gene Ther. 2000;7(5):806-812.

[9] Jacobs A, Voges J, Reszka R, et al. Positronemission tomography of vector-mediated gene expression in gene therapy for gliomas. Lancet. 2001;358(9283):727-729.

[10] Rubsam LZ, Davidson BL, Shewach DS. Superior cytotoxicity with ganciclovir compared with acyclovir and $1-\beta-\mathrm{D}$-arabinofuranosylthymine in herpes simplex virus-thymidine kinase-expressing cells: a novel paradigm for cell killing. Cancer Res. 1998;58(17):3873-3882.

[11] Thust R, Tomicic M, Klocking R, Wutzler P, Kaina B. Cytogenetic genotoxicity of anti-herpes purine nucleoside analogues in $\mathrm{CHO}$ cells expressing the thymidine kinase gene of herpes simplex virus type 1: comparison of ganciclovir, penciclovir and 
aciclovir. Mutagenesis. 2000;15(2):177-184.

[12] Fick J, Barker FG 2nd, Dazin P, Westphale EM, Beyer EC, Israel MA. The extent of heterocellular communication mediated by gap junctions is predictive of bystander tumor cytotoxicity in vitro. Proc Natl Acad Sci USA. 1995;92(24):11071-11075.

[13] Denning C, Pitts JD. Bystander effects of different enzyme-prodrug systems for cancer gene therapy depend on different pathways for intercellular transfer of toxic metabolites, a factor that will govern clinical choice of appropriate regimes. Hum Gene Ther. 1997;8(15):1825-1835.

[14] Kianmanesh AR, Perrin H, Panis Y, et al. A "distant" bystander effect of suicide gene therapy: regression of nontransduced tumors together with a distant transduced tumor. Hum Gene Ther. 1997;8(15):1807-1814.

[15] Eaton JD, Perry MJA, Todryk SM, et al. Genetic prodrug activation therapy (GPAT) in two rat prostate models generates an immune bystander effect and can be monitored by magnetic resonance techniques. Gene Ther. 2001;8(7):557-567.

[16] Kramm CM, Korholz D, Rainov NG, et al. Systemic activation of the immune system during ganciclovir treatment following intratumoral herpes simplex virus type 1 thymidine kinase gene transfer in an adolescent ependymoma patient. Neuropediatrics. 2002;33(1):6-9.

[17] Rainov NG, Fetell M, Cloughesy T, et al. A phase III clinical evaluation of herpes simplex virus type 1 thymidine kinase and ganciclovir gene therapy as an adjuvant to surgical resection and radiation in adults with previously untreated glioblastoma multiforme. Hum Gene Ther. 2000;11(17):2389-2401.

[18] Kokoris MS, Sabo P, Black ME. In vitro evaluation of mutant HSV-1 thymidine kinases for suicide gene therapy. Anticancer Res. 2000;20(2A):959-963.

[19] Black ME, Kokoris MS, Sabo P. Herpes simplex virus-1 thymidine kinase mutants created by semi-random sequence mutagenesis improve prodrug-mediated tumor cell killing. Cancer Res. 2001;61(7):3022-3026.

[20] Hinds TA, Compadre C, Hurlburt BK, Drake RR. Conservative mutations of glutamine- 125 in herpes simplex virus type 1 thymidine kinase result in a ganciclovir kinase with minimal deoxypyrimidine kinase activities. Biochemistry. 2000;39(14):41054111.

[21] Kokoris MS, Sabo P, Adman ET, Black ME. Enhancement of tumor ablation by a selected HSV-1 thymidine kinase mutant. Gene Ther. 1999;6(8):1415-1426.

[22] Kuriyama N, Kuriyama H, Julin CM, Lamborn KR, Israel MA. Protease pretreatment increases the efficacy of adenovirus-mediated gene therapy for the treatment of an experimental glioblastoma model. Cancer Res. 2001;61(5):1805-1809.
[23] Jones RK, Pope IM, Kinsella AR, Watson AJM, Christmas SE. Combined suicide and granulocytemacrophage colony-stimulating factor gene therapy induces complete tumor regression and generates antitumor immunity. Cancer Gene Ther. 2000;7(12):1519-1528.

[24] Marples B, Greco O, Joiner MC, Scott SD. Molecular approaches to chemo-radiotherapy. Eur J Cancer. 2002;38(2):231-239.

[25] Nishihara E, Nagayama Y, Mawatari F, et al. Retrovirus-mediated herpes simplex virus thymidine kinase gene transduction renders human thyroid carcinoma cell lines sensitive to ganciclovir and radiation in vitro and in vivo. Endocrinology. 1997;138(11):4577-4583.

[26] Atkinson G, Hall SJ. Prodrug activation gene therapy and external beam irradiation in the treatment of prostate cancer. Urology. 1999;54(6):1098-2104.

[27] Park JY, Elshami AA, Amin K, Rizk N, Kaiser LR, Albelda SM. Retinoids augment the bystander effect in vitro and in vivo in herpes simplex virus thymidine kinase/ganciclovir-mediated gene therapy. Gene Ther. 1997;4(9):909-917.

[28] Wildner O, Blaese RM, Candotti F. Enzyme prodrug gene therapy: synergistic use of the herpes simplex virus-cellular thymidine kinase/ganciclovir system and thymidylate synthase inhibitors for the treatment of colon cancer. Cancer Res. 1999;59(20):5233-5238.

[29] Wildner O, Blaese RM, Morris JC. Synergy between the herpes simplex virus tk/ganciclovir prodrug suicide system and the topoisomerase I inhibitor topotecan. Hum Gene Ther. 1999;10(16):2679_ 2687.

[30] Balzarini J, Degreve B, Andrei G, et al. Superior cytostatic activity of the ganciclovir elaidic acid ester due to the prolonged intracellular retention of ganciclovir anabolites in herpes simplex virus type 1 thymidine kinase gene-transfected tumor cells. Gene Ther. 1998;5(3):419-426.

[31] Shaw MM, Gurr WK, Watts PA, Littler E, Field HJ. Ganciclovir and penciclovir, but not acyclovir, induce apoptosis in herpes simplex virus thymidine kinase-transformed baby hamster kidney cells. Antiviral Chem Chemother. 2001;12:175-186

[32] Thust R, Tomicic M, Klocking R, Voutilainen N, Wutzler P, Kaina B. Comparison of the genotoxic and apoptosis-inducing properties of ganciclovir and penciclovir in Chinese hamster ovary cells transfected with the thymidine kinase gene of herpes simplex virus-1: implications for gene therapeutic approaches. Cancer Gene Ther. 2000;7(1):107-117.

[33] Tong XW, Engehausen DG, Kaufman RH, et al. Improvement of gene therapy for ovarian cancer by using acyclovir instead of ganciclovir in adenovirus mediated thymidine kinase gene therapy. 
Anticancer Res. 1998;18(2A):713-718.

[34] Valerie K, Brust D, Farnsworth J, et al. Improved radiosensitization of rat glioma cells with adenovirus-expressed mutant herpes simplex virus-thymidine kinase in combination with acyclovir. Cancer Gene Ther. 2000;7(6):879-884.

[35] Hasenburg A, Tong XW, Fischer DC, et al. Adenovirus-mediated thymidine kinase gene therapy in combination with topotecan for patients with recurrent ovarian cancer: 2.5-year follow-up. Gynecol Oncol. 2001;83(3):549-554.

[36] Hasenburg A, Tong XW, Rojas-Martinez A, et al. Thymidine kinase (TK) gene therapy of solid tumors: valacyclovir facilitates outpatient treatment. Anticancer Res. 1999;19(3B):2163-2165.

[37] Teh BS, Aguilar-Cordova E, Kernen K, et al. Phase I/II trial evaluating combined radiotherapy and in situ gene therapy with or without hormonal therapy in the treatment of prostate cancer-a preliminary report. Int J Radiat Oncol Biol Phys. 2001;51(3):605-613.

[38] Shalev M, Kadmon D, Teh BS, et al. Suicide gene therapy toxicity after multiple and repeat injections in patients with localized prostate cancer. J Urol. 2000;163(6):1747-1750.

[39] Basnak I, Otter GP, Duncombe RJ, et al. Efficient syntheses of (E)-5-(2-bromovinyl)-2'-deoxy$4^{\prime}$-thiouridine; a nucleoside analogue with potent biological activity. Nucleosides Nucleotides. 1998;17(1-3):29-38.

[40] Hamel W, Zirkel D, Mehdorn HM, Westphal M, Israel MA. (E)-5-(2-bromovinyl)-2'-deoxyuridine potentiates ganciclovir-mediated cytotoxicity on herpes simplex virus-thymidine kinase-expressing cells. Cancer Gene Ther. 2001;8(5):388-396.

[41] Degreve B, De Clercq E, Balzarini J. Bystander effect of purine nucleoside analogues in HSV-1 tk suicide gene therapy is superior to that of pyrimidine nucleoside analogues. Gene Ther. 1999;6(2):162-170.

[42] Hlubinova K, Hlavaty J, Altaner C. Human glioma cells expressing herpes simplex virus thymidine kinase gene treated with acyclovir, ganciclovir and bromovinyldeoxyuridine. Evaluation of their activity in vitro and in nude mice. Neoplasma. 2001;48(5):398-406.

[43] Grignet-Debrus C, Cool V, Baudson N, Velu T, Calberg-Bacq CM. The role of cellular- and prodrug-associated factors in the bystander effect induced by the Varicella zoster and Herpes simplex viral thymidine kinases in suicide gene therapy. Cancer Gene Ther. 2000;7(11):1456-1468.

[44] Grignet-Debrus C, Calberg-Bacq CM. Potential of Varicella zoster virus thymidine kinase as a suicide gene in breast cancer cells. Gene Ther. 1997;4(6):560-569.

[45] Christians FC, Scapozza L, Crameri A, Folkers G, Stemmer WP. Directed evolution of thymidine kinase for AZT phosphorylation using DNA family shuffling. Nat Biotechnol. 1999;17(3):259-264.

[46] Marquez VE, Siddiqui MA, Ezzitouni A, et al. Nucleosides with a twist. Can fixed forms of sugar ring pucker influence biological activity in nucleosides and oligonucleotides? J Med Chem. 1996;39(19):3739-3747.

[47] Prota A, Vogt J, Pilger B, et al. Kinetics and crystal structure of the wild-type and the engineered Y101F mutant of Herpes simplex virus type 1 thymidine kinase interacting with (North)-methanocarba-thymidine. Biochemistry. 2000;39(31):9597-9603.

[48] Noy R, Ben-Zvi Z, Manor E, et al. Antitumor activity and metabolic activation of $\mathrm{N}$ methanocarbathymidine, a novel thymidine analogue with a pseudosugar rigidly fixed in the northern conformation, in murine colon cancer cells expressing herpes simplex thymidine kinase. $\mathrm{Mol}$ Cancer Ther. 2002;1:585-593.

[49] Ireton GC, McDermott G, Black ME, Stoddard BL. The structure of Escherichia coli cytosine deaminase. J Mol Biol. 2002;315(4):687-697.

[50] Haberkorn U, Oberdorfer F, Gebert J, et al. Monitoring gene therapy with cytosine deaminase: in vitro studies using tritiated-5-fluorocytosine. $\mathrm{J} \mathrm{Nucl}$ Med. 1996;37(1):87-94.

[51] Stegman LD, Rehemtulla A, Beattie B, et al. Noninvasive quantitation of cytosine deaminase transgene expression in human tumor xenografts with in vivo magnetic resonance spectroscopy. Proc Natl Acad Sci USA. 1999;96(17):9821-9826.

[52] Lawrence TS, Rehemtulla A, Ng EY, Wilson M, Trosko JE, Stetson PL. Preferential cytotoxicity of cells transduced with cytosine deaminase compared to bystander cells after treatment with 5flucytosine. Cancer Res. 1998;58(12):2588-2593.

[53] Huber BE, Richards CA, Austin EA. VDEPT: an enzyme/prodrug gene therapy approach for the treatment of metastatic colorectal cancer. Advanced Drug Delivery Reviews. 1995;17:279-292.

[54] Nyati MK, Sreekumar A, Li S, et al. High and selective expression of yeast cytosine deaminase under a carcinoembryonic antigen promoter-enhancer. Cancer Res. 2002;62(8):2337-2342.

[55] Li Z, Shanmugam N, Katayose D, et al. Enzyme/prodrug gene therapy approach for breast cancer using a recombinant adenovirus expressing Escherichia coli cytosine deaminase. Cancer Gene Ther. 1997;4(2):113-117.

[56] Miller CR, Williams CR, Buchsbaum DJ, Gillespie GY. Intratumoral 5-fluorouracil produced by cytosine deaminase/5-fluorocytosine gene therapy is effective for experimental human glioblastomas. Cancer Res. 2002;62(3):773-780.

[57] Topf N, Worgall S, Hackett NR, Crystal RG. Regional "pro-drug" gene therapy: intravenous 
administration of an adenoviral vector expressing the E. coli cytosine deaminase gene and systemic administration of 5-fluorocytosine suppresses growth of hepatic metastasis of colon carcinoma. Gene Ther. 1998;5(4):507-513.

[58] O'Keefe DS, Uchida A, Bacich DJ, et al. Prostatespecific suicide gene therapy using the prostatespecific membrane antigen promoter and enhancer. Prostate. 2000;45(2):149-157.

[59] Kievit E, Bershad E, Ng E, et al. Superiority of yeast over bacterial cytosine deaminase for enzyme/prodrug gene therapy in colon cancer xenografts. Cancer Res. 1999;59(7):1417-1421.

[60] Kievit E, Nyati MK, Ng E, et al. Yeast cytosine deaminase improves radiosensitization and bystander effect by 5-fluorocytosine of human colorectal cancer xenografts. Cancer Res. 2000;60(23):6649-6655.

[61] Kuriyama S, Mitoro A, Yamazaki M, et al. Comparison of gene therapy with the herpes simplex virus thymidine kinase gene and the bacterial cytosine deaminase gene for the treatment of hepatocellular carcinoma. Scand J Gastroenterol. 1999;34(10):1033-1041.

[62] Rogers RP, Ge JQ, Holley-Guthrie E, et al. Killing Epstein-Barr virus-positive B lymphocytes by gene therapy: comparing the efficacy of cytosine deaminase and herpes simplex virus thymidine kinase. Hum Gene Ther. 1999;7(18):2235-2245.

[63] Shirakawa T, Gardner TA, Ko SC, et al. Cytotoxicity of adenoviral-mediated cytosine deaminase plus 5-fluorocytosine gene therapy is superior to thymidine kinase plus acyclovir in a human renal cell carcinoma model. J Urol. 1999;162(pt 1):949-954.

[64] Trinh QT, Austin EA, Murray DM, Knick VC, Huber BE. Enzyme/prodrug gene therapy: comparison of cytosine deaminase/5-fluorocytosine versus thymidine kinase/ganciclovir enzyme/prodrug systems in a human colorectal carcinoma cell line. Cancer Res. 1995;55(21):4808-4812.

[65] Adachi Y, Tamiya T, Ichikawa T, et al. Experimental gene therapy for brain tumors using adenovirusmediated transfer of cytosine deaminase gene and uracil phosphoribosyltransferase gene with 5fluorocytosine. Hum Gene Ther. 2000;11(1):77-89.

[66] Koyama F, Sawada H, Hirao T, Fujii H, Hamada $\mathrm{H}$, Nakano H. Combined suicide gene therapy for human colon cancer cells using adenovirusmediated transfer of Escherichia coli cytosine deaminase gene and Escherichia coli uracil phosphoribosyltransferase gene with 5-fluorocytosine. Cancer Gene Ther. 2000;7(7):1015-1022.

[67] Rogulski KR, Kim JH, Kim SH, Freytag SO. Glioma cells transduced with an Escherichia coli CD/HSV1 TK fusion gene exhibit enhanced metabolic suicide and radiosensitivity. Hum Gene Ther. 1997;8(1):73-85.
[68] Aghi M, Kramm CM, Chou TC, Breakefield $\mathrm{XO}$, Chiocca EA. Synergistic anticancer effects of ganciclovir/thymidine kinase and 5fluorocytosine/cytosine deaminase gene therapies. J Natl Cancer Inst. 1998;90(5):370-380.

[69] Hanna NN, Mauceri HJ, Wayne JD, Hallahan DE, Kufe DW, Weichselbaum RR. Virally directed cytosine deaminase/5-fluorocytosine gene therapy enhances radiation response in human cancer xenografts. Cancer Res. 1997;57(19):4205-4209.

[70] Pederson LC, Buchsbaum DJ, Vickers SM et al. Molecular chemotherapy combined with radiation therapy enhances killing of cholangiocarcinoma cells in vitro and in vivo. Cancer Res. 1997;57(19):4325-4332.

[71] Gabel M, Kim JH, Kolozsvary A, Khil M, Freytag S. Selective in vivo radiosensitization by 5 fluorocytosine of human colorectal carcinoma cells transduced with the E. coli cytosine deaminase (CD) gene. Int J Radiat Oncol Biol Phys. 1998;41(4):883-887.

[72] Pandha HS, Martin LA, Rigg A, et al. Genetic prodrug activation therapy for breast cancer: A phase I clinical trial of erbB-2-directed suicide gene expression. J Clin Oncol. 1999;17(7):2180-2189.

[73] Mao C, Cook WJ, Zhou M, Koszalka GW, Krenitsky TA, Ealick SE. The crystal structure of Escherichia coli purine nucleoside phosphorylase: a comparison with the human enzyme reveals a conserved topology. Structure. 1997;5(10):1373-1383.

[74] Gadi VK, Alexander SD, Kudlow JE, Allan P, Parker $\mathrm{WB}$, Sorscher EJ. In vivo sensitization of ovarian tumors to chemotherapy by expression of E. coli purine nucleoside phosphorylase in a small fraction of cells. Gene Ther. 2000;7(20):1738-1743.

[75] Lockett LJ, Molloy PL, Russell PJ, Both GW. Relative efficiency of tumor cell killing in vitro by two enzyme-prodrug systems delivered by identical adenovirus vectors. Clin Cancer Res. 1997;3(11):2075-2080.

[76] Martiniello-Wilks R, Garcia-Aragon J, Daja MM, et al. In vivo gene therapy for prostate cancer: preclinical evaluation of two different enzyme-directed prodrug therapy systems delivered by identical adenovirus vectors. Hum Gene Ther. 1998;9(11):16171626.

[77] Mohr L, Shankara S, Yoon SK, et al. Gene therapy of hepatocellular carcinoma in vitro and in vivo in nude mice by adenoviral transfer of the Escherichia coli purine nucleoside phosphorylase gene. Hepatology. 2000;31(3):606-614.

[78] Parker WB, King SA, Allan PW, et al. In vivo gene therapy of cancer with E. coli purine nucleoside phosphorylase. Hum Gene Ther. 1997;8(14):16371644.

[79] Krohne TU, Shankara S, Geissler M, et al. Mechanisms of cell death induced by suicide genes 
encoding purine nucleoside phosphorylase and thymidine kinase in human hepatocellular carcinoma cells in vitro. Hepatology. 2001;34(3):511518.

[80] Waxman DJ, Chen L, Hecht JE, Jounaidi Y. Cytochrome P450-based cancer gene therapy: recent advances and future prospects. Drug Metab Rev. 1999;31(2):503-522.

[81] Chen L, Waxman DJ. Intratumoral activation and enhanced chemotherapeutic effect of oxazaphosphorines following cytochrome P-450 gene transfer: development of a combined chemotherapy/cancer gene therapy strategy. Cancer Res. 1995;55(3):581-589.

[82] Wei MX, Tamiya T, Rhee RJ, Breakefield XO, Chiocca EA. Diffusible cytotoxic metabolites contribute to the in vitro bystander effect associated with the cyclophosphamide/cytochrome P450 2B1 cancer gene therapy paradigm. Clin Cancer Res. 1995;1(10):1171-1177.

[83] Manome Y, Wen PY, Chen L, et al. Gene therapy for malignant gliomas using replication incompetent retroviral and adenoviral vectors encoding the cytochrome P450 2B1 gene together with cyclophosphamide. Gene Ther. 1996;3(6):513-520.

[84] Chen L, Yu LJ, Waxman DJ. Potentiation of cytochrome P450/cyclophosphamide-based cancer gene therapy by coexpression of the P450 reductase gene. Cancer Res. 1997;57(21):4830-4837.

[85] Huang Z, Raychowdhury MK, Waxman DJ. Impact of liver P450 reductase suppression on cyclophosphamide activation, pharmacokinetics and antitumoral activity in a cytochrome P450-based cancer gene therapy model. Cancer Gene Ther. 2000;7(7):1034-1042.

[86] Huang Z, Waxman DJ. Modulation of cyclophosphamide-based cytochrome P450 gene therapy using liver P450 inhibitors. Cancer Gene Ther. 2001;8(6):450-458.

[87] Zhou D, Lu Y, Steiner MS, Dalton JT. Cytochrome P-450 2C9 sensitizes human prostate tumor cells to cyclophosphamide via a bystander effect. Antimicrob Agents Chemother. 2000;44(10):2659-2663.

[88] Jounaidi Y, Hecht JE, Waxman DJ. Retroviral transfer of human cytochrome P450 genes for oxazaphosphorine-based cancer gene therapy. Cancer Res. 1998;58(19):4391-4401.

[89] Kan O, Griffiths L, Baban D, et al. Direct retroviral delivery of human cytochrome P450 2B6 for genedirected enzyme prodrug therapy of cancer. Cancer Gene Ther. 2001;8(7):473-482.

[90] Jounaidi Y, Waxman DJ. Frequent, moderate-dose cyclophosphamide administration improves the efficacy of cytochrome P-450/cytochrome P-450 reductase-based cancer gene therapy. Cancer Res. 2001;61(11):4437-4444.

[91] Karle P, Renner M, Salmons B, Gunzburg WH.
Necrotic, rather than apoptotic, cell death caused by cytochrome P450-activated ifosfamide. Cancer Gene Ther. 2001;8(3):220-230.

[92] Kammertoens T, Gelbmann W, Karle P, et al. Combined chemotherapy of murine mammary tumors by local activation of the prodrugs ifosfamide and 5-fluorocytosine. Cancer Gene Ther. 2000;7(4):629-636.

[93] Lohr M, Muller P, Karle P, et al. Targeted chemotherapy by intratumour injection of encapsulated cells engineered to produce CYP2B1, an ifosfamide activating cytochrome P450. Gene Ther. 1998;5(8):1070-1078.

[94] Jounaidi Y, Waxman DJ. Combination of the bioreductive drug tirapazamine with the chemotherapeutic prodrug cyclophosphamide for P450/P450reductase-based cancer gene therapy. Cancer Res. 2000;60(14):3761-3769.

[95] Thatcher NJ, Edwards RJ, Lemoine NR, Doehmer J, Davies DS. The potential of acetaminophen as a prodrug in gene-directed enzyme prodrug therapy. Cancer Gene Ther. 2000;7(4):521-525.

[96] Rainov NG, Dobberstein KU, Sena-Esteves M, et al. New prodrug activation gene therapy for cancer using cytochrome P450 4B1 and 2aminoanthracene/4-ipomeanol. Hum Gene Ther. 1998;9(9):1261-1273.

[97] Mohr L, Rainov NG, Mohr UG, Wands JR. Rabbit cytochrome P450 4B1: A novel prodrug activating gene for pharmacogene therapy of hepatocellular carcinoma. Cancer Gene Ther. 2000;7(7):10081014.

[98] Frank S, Steffens S, Fischer U, Tlolko A, Rainov NG, Kramm CM. Differential cytotoxicity and bystander effect of the rabbit cytochrome P450 4B1 enzyme gene by two different prodrugs: implications for pharmacogene therapy. Cancer Gene Ther. 2002;9(2):178-188.

[99] Springer CJ, Antoniw P, Bagshawe KD, Searle F, Bisset GM, Jarman M. Novel prodrugs which are activated to cytotoxic alkylating agents by carboxypeptidase G2. J Med Chem. 1990;33(2):677-681.

[100] Marais R, Spooner RA, Light Y, Martin J, Springer CJ. Gene-directed enzyme prodrug therapy with a mustard prodrug/carboxypeptidase G2 combination. Cancer Res. 1996;56(20):4735-4742.

[101] Spooner RA, Martin J, Friedlos F, Marais R, Springer CJ. In suicide gene therapy, the site of subcellular localization of the activating enzyme is more important than the rate at which it activates prodrug. Cancer Gene Ther. 2000;7(10):1348-1356.

[102] Stribbling SM, Friedlos F, Martin J, et al. Regressions of established breast carcinoma xenografts by carboxypeptidase G2 suicide gene therapy and the prodrug CMDA are due to a bystander effect. Hum Gene Ther. 2000;11(2):285-292.

[103] Niculescu-Duvaz I, Friedlos F, Niculescu-Duvaz D, 
Davies L, Springer CJ. Prodrugs for antibodyand gene-directed enzyme prodrug therapies (ADEPT and GDEPT). Anticancer Drug Des. 1999;14(6):517-538.

[104] Niclescu-Duvaz D, Niculescu-Duvaz I, Friedlos F, et al. Self-immolative nitrogen mustard prodrugs for suicide gene therapy. J Med Chem. 1998;41(26):5297-5309.

[105] Webley SD, Francis RJ, Pedley RB, et al. Measurement of the critical DNA lesions produced by antibody-directed enzyme prodrug therapy (ADEPT) in vitro, in vivo and in clinical material. Br J Cancer. 2001;84(12):1671-1676.

[106] Friedlos F, Davies L, Scanlon I, et al. Three new prodrugs for suicide gene therapy using carboxypeptidase G2 elicit bystander efficacy in two xenograft models. Cancer Res. 2002;62(6):1724-1729.

[107] Niculescu-Duvaz I, Niculescu-Duvaz D, Friedlos F, et al. Self-immolative anthracycline prodrugs for suicide gene therapy. J Med Chem. 1999;42(13):2485-2489.

[108] Hamstra DA, Rehemtulla A. Toward an enzyme/prodrug strategy for cancer gene therapy: endogenous activation of carboxypeptidase A mutants by the PACE/Furin family of propeptidases. Hum Gene Ther. 1999;10(2):235-248.

[109] Hamstra DA, Page M, Maybaum J, Rehemtulla A. Expression of endogenously activated secreted or cell surface carboxypeptidase A sensitizes tumor cells to methotrexate- $\alpha$-peptide prodrugs. Cancer Res. 2000;60(3):657-665.

[110] Wierdl M, Morton CL, Weeks JK, Danks MK, Harris LC, Potter PM. Sensitization of human tumor cells to CPT-11 via adenoviral-mediated delivery of a rabbit liver carboxylesterase. Cancer Res. 2001;61(13):5078-5082.

[111] Ogasawara H, Nishio K, Takeda Y, et al. A novel antitumor antibiotic, KW-2189 is activated by carboxyl esterase and induces DNA strand breaks in human small cell lung cancer cells. Jpn J Cancer Res. 1994;85(4):418-425.

[112] Kojima A, Hackett NR, Ohwada A, Crystal RG. In vivo human carboxylesterase cDNA gene transfer to activate the prodrug CPT-11 for local treatment of solid tumors. J Clin Invest. 1998;101(8):17891796.

[113] Meck MM, Wierdl M, Wagner LM, et al. A virus-directed enzyme prodrug therapy approach to purging neuroblastoma cells from hematopoietic cells using adenovirus encoding rabbit carboxylesterase and CPT-11. Cancer Res. 2001; 61(13):5083-5089.

[114] Farquhar D, Cherif A, Bakina E, Nelson JA. Intensely potent doxorubicin analogues: structureactivity relationship. J Med Chem. 1998;41(6):965972.

[115] Hansch C, Leo A. Substituent Constants for Cor- relation Analysis in Chemistry and Biology. New York, NY: Wiley; 1979.

[116] Zenno S, Koike H, Tanokura M, Saigo K. Gene cloning, purification, and characterization of $\mathrm{NfsB}$, a minor oxygen-insensitive nitroreductase from Escherichia coli, similar in biochemical properties to FRase I, the major flavin reductase in Vibrio fischeri. J Biochem (Tokyo). 1996;120(4):736-744.

[117] Anlezark GM, Melton RG, Sherwood RF, Coles B, Friedlos F, Knox RJ. The bioactivation of 5(aziridin-1-yl)-2,4-dinitrobenzamide (CB1954)I. Purification and properties of a nitroreductase enzyme from Escherichia coli-a potential enzyme for antibody-directed enzyme prodrug therapy (ADEPT). Biochem Pharmacol. 1992;44(12):22892295.

[118] Parkinson GN, Skelly JV, Neidle S. Crystal structure of FMN-dependent nitroreductase from Escherichia coli B: a prodrug-activating enzyme. J Med Chem. 2000;43(20):3624-3631.

[119] Lovering AL, Hyde EI, Searle PF, White SA. The structure of Escherichia coli nitroreductase complexed with nicotinic acid: three crystal forms at $1.7 \mathrm{~A}, 1.8 \mathrm{~A}$ and $2.4 \mathrm{~A}$ resolution. J Mol Biol. 2001;309(1):203-213.

[120] Knox RJ, Friedlos F, Marchbank T, Roberts JJ. Bioactivation of CB 1954: reaction of the active 4hydroxylamino derivative with thioesters to form the ultimate DNA-DNA interstrand crosslinking species. Biochem Pharmacol. 1991;42(9):16911697.

[121] Friedlos F, Court S, Ford M, Denny WA, Springer C. Gene-directed enzyme prodrug therapy: quantitative bystander cytotoxicity and DNA damage induced by CB1954 in cells expressing bacterial nitroreductase. Gene Ther. 1998;5(1):105-112.

[122] Bridgewater JA, Knox RJ, Pitts JD, Collins MK, Springer CJ. The bystander effect of the nitroreductase/CB1954 enzyme/prodrug system is due to a cell-permeable metabolite. Hum Gene Ther. 1997;8(6):709-717.

[123] McNeish IA, Green NK, Gilligan MG, et al. Virus directed enzyme prodrug therapy for ovarian and pancreatic cancer using retrovirally delivered E. coli nitroreductase and CB1954. Gene Ther. 1998;5(8):1061-1069.

[124] Green NK, Youngs DJ, Neoptolemos JP, et al. Sensitization of colorectal and pancreatic cancer cell lines to the prodrug 5-(aziridin-1-yl)-2,4dinitrobenzamide (CB1954) by retroviral transduction and expression of the E. coli nitroreductase gene. Cancer Gene Ther. 1997;4(4):229-238.

[125] Djeha AH, Hulme A, Dexter MT, et al. Expression of Escherichia coli B nitroreductase in established human tumor xenografts in mice results in potent antitumoral and bystander effects upon systemic administration of the prodrug CB1954. 
Cancer Gene Ther. 2000;7(5):721-731.

[126] Westphal EM, Ge J, Catchpole JR, Ford M, Kenney SC. The nitroreductase/CB1954 combination in Epstein-Barr virus-positive B-cell lines: induction of bystander killing in vitro and in vivo. Cancer Gene Ther. 2000;7(1):97-106.

[127] Cui W, Gusterson BA, Clark AJ. Inhibition of mycdependent breast tumor formation in transgenic mice. Breast Cancer Res Treat. 2002;71(1):9-20.

[128] Chung-Faye G, Palmer D, Anderson D, et al. Virusdirected, enzyme prodrug therapy with nitroimidazole reductase: a phase I and pharmacokinetic study of its prodrug, CB1954. Clin Cancer Res. 2001;7(9):2662-2668.

[129] Anlezark GM, Melton RG, Sherwood RF, et al. Bioactivation of dinitrobenzamide mustards by an E. coli B nitroreductase. Biochem Pharmacol. 1995;50(5):609-618.

[130] Palmer BD, van Zijl P, Denny WA, Wilson WR. Reductive chemistry of the novel hypoxia-selective cytotoxin 5-[N,N-bis(2-chloroethyl)amino]-2,4dinitrobenzamide. J Med Chem. 1995;38(7):12291241.

[131] Kestell P, Pruijn FB, Siim BG, Palmer BD, Wilson WR. Pharmacokinetics and metabolism of the nitrogen mustard bioreductive drug 5. Cancer Chemother Pharmacol. 2000;46(5):365-374.

[132] Palmer BD, Wilson WR, Cliffe S, Denny WA. Hypoxia-selective antitumor agents. 5. Synthesis of water-soluble nitroaniline mustards with selective cytotoxicity for hypoxic mammalian cells. $\mathrm{J}$ Med Chem. 1992;35(17):3214-3222.

[133] Palmer BD, Wilson WR, Atwell GJ, Schultz D, Xu XZ, Denny WA. Hypoxia-selective antitumor agents. 9. Structure-activity relationships for hypoxia-selective cytotoxicity among analogues of 5-[N,N-bis(2-chloroethyl)amino]-2,4dinitrobenzamide. J Med Chem. 1994;37(14):21752184.

[134] Atwell GJ, Boyd M, Palmer BD, et al. Synthesis and evaluation of 4-substituted analogues of 5-[N,Nbis (2-chloroethyl)amino]-2-nitrobenzamide as bioreductively activated prodrugs using an Escherichia coli nitroreductase. Anticancer Drug Des. 1996;11(7):553-567.

[135] Friedlos F, Denny WA, Palmer BD, Springer CJ. Mustard prodrugs for activation by Escherichia coli nitroreductase in gene-directed enzyme prodrug therapy. J Med Chem. 1997;40(8):1270-1275.

[136] Wardman P. Some reactions and properties of nitro radical-anions important in biology and medicine. Environ Health Perspect. 1985;64:309-320.

[137] Mauger AB, Burke PJ, Somani HH, Friedlos F, Knox RJ. Self-immolative prodrugs: candidates for antibody-directed enzyme prodrug therapy in conjunction with a nitroreductase enzyme. J Med Chem. 1994;37(21):3452-3458.
[138] Sykes BM, Hay MP, Bohinc-Herceg D, Helsby NA, O'Connor CJ, Denny WA. Leaving group effects in reductively-triggered fragmentation of 4nitrobenzyl carbamates. J Chem Soc [Perkin 1]. 2000;(10):1601-1608.

[139] Denny WA. Prodrug strategies in cancer therapy. Eur J Med Chem. 2001;36(7-8):577-595.

[140] Sagnou MJ, Howard PW, Gregson SJ, EnoAmooquaye E, Burke PJ, Thurston DE. Design and synthesis of novel pyrrolobenzodiazepine (PBD) prodrugs for ADEPT and GDEPT. Bioorg Med Chem Lett. 2000;10(18):2083-2086.

[141] Lee M, Simpson JE, Woo S, et al. Synthesis of an aminopropyl analog of the experimental anticancer drug tallimustine, and activation of its 4nitrobenzylcarbamoyl prodrug by nitroreductase and NADH. Bioorg Med Chem Lett. 1997;7:10651070.

[142] Hay MP, Wilson WR, Denny WA. Nitrobenzyl carbamate prodrugs of enediynes for nitroreductase gene-directed enzyme prodrug therapy (GDEPT). Bioorg Med Chem Lett. 1999;9(24):3417-3422.

[143] Hay MP, Sykes BM, Denny WA, Wilson WR. A 2-nitroimidazole carbamate prodrug of 5-amimo1-(chloromethyl)-3-[(5,6,7-trimethoxyindol2-yl)carbonyl]-1,2-dihydro-3H-benz[E]indole (amino-seco-CBI-TMI) for use with ADEPT and GDEPT. Bioorg Med Chem Lett. 1999;9(15):22372242.

[144] Bailey SM, Knox RJ, Hobbs SM, et al. Investigation of alternative prodrugs for use with E. coli nitroreductase in "suicide gene" approaches to cancer therapy. Gene Ther. 1996;3(12):1143-1150.

[145] Wardman P. Indole-3-acetic acids and horseradish peroxidase: a new prodrug/enzyme combination for targeted cancer therapy. Curr Pharm Des. 2002;8(15):1363-1374.

[146] Greco O, Folkes LK, Wardman P, Tozer GM, Dachs GU. Development of a novel enzyme/prodrug combination for gene therapy of cancer: horseradish peroxidase/indole-3-acetic acid. Cancer Gene Ther. 2000;7(11):1414-1420.

[147] Greco O, Tozer GM, Dachs GU. Oxic and anoxic enhancement of radiation-mediated toxicity by horseradish peroxidase/indole-3-acetic acid gene therapy. Int J Radiat Biol. 2002;78(3):173-181.

[148] Folkes LK, Greco O, Dachs GU, Stratford MR, Wardman P. 5-fluoroindole-3-acetic acid: a prodrug activated by a peroxidase with potential for use in targeted cancer therapy. Biochem Pharmacol. 2002;63(2):265-272.

[149] Tamiya T, Ono Y, Wei MX, Mroz PJ, Moolten FL, Chiocca EA. Escherichia coli gpt gene sensitizes rat glioma cells to killing by 6-thioxanthine or 6thioguanine. Cancer Gene Ther. 1996;3(3):155-162.

[150] Ono Y, Ikeda K, Wei MX, Harsh GR 4th, Tamiya T, Chiocca EA. Regression of experimental brain 
tumors with 6-thioxanthine and Escherichia coli gpt gene therapy. Hum Gene Ther. 1997;8(17): 2043-2055.

[151] Fonseca MJ, Storm G, Hennink WE, Gerritsen WR, Haisma HJ. Cationic polymeric gene delivery of beta-glucuronidase for doxorubicin prodrug therapy. J Gene Med. 1999;1(6):407-414.

[152] Weyel D, Sedlacek HH, Muller R, Brusselbach S. Secreted human beta-glucuronidase: a novel tool for gene-directed enzyme prodrug therapy. Gene Ther. 2000;7(3):224-231.

[153] Heine D, Muller R, Brusselbach S. Cell surface display of a lysosomal enzyme for extracellular gene-directed enzyme prodrug therapy. Gene Ther. 2001;8(13):1005-1010.

[154] Bakina E, Farquhar D. Intensely cytotoxic anthracycline prodrugs: galactosides. Anticancer Drug Des. 1999;14(6):507-515.

[155] Bakina E, Wu Z, Rosenblum M, Farquhar D. Intensely cytotoxic anthracycline prodrugs: glucuronides. J Med Chem. 1997;40(25):4013-4018.

[156] Evrard A, Cuq P, Ciccolini J, Vian L, Cano JP. Increased cytotoxicity and bystander effect of 5fluorouracil and 5-deoxy-5-fluorouridine in human colorectal cancer cells transfected with thymidine phosphorylase. Br J Cancer. 1999;80(11): 1726-1733.

[157] Kato Y, Matsukawa S, Muraoka R, Tanigawa N. Enhancement of drug sensitivity and a bystander effect in PC-9 cells transfected with a platelet-derived endothelial cell growth factor thymidine phosphorylase cDNA. Br J Cancer. 1997;75(4):506-511.

[158] Patterson AV, Zhang H, Moghaddam A, et al. Increased sensitivity to the prodrug 5'-deoxy5 -fluorouridine and modulation of 5-fluoro- $2^{\prime}$ deoxyuridine sensitivity in MCF-7 cells transfected with thymidine phosphorylase. Br J Cancer. 1995; 72(3):669-675.

[159] Hoffman RM, Erbe RW. High in vivo rates of methionine biosynthesis in transformed human and malignant rat cells auxotrophic for methionine. Proc Natl Acad Sci USA. 1976;73(5):1523-1527.

[160] Miki K, Xu M, Gupta A, et al. Methioninase cancer gene therapy with selenomethionine as suicide prodrug substrate. Cancer Res. 2001;61(18):68056510.

* Corresponding author.

E-mail: b.denny@auckland.ac.nz

Fax: +64 9373 7502; Tel: +64 93737599 ext 6144 

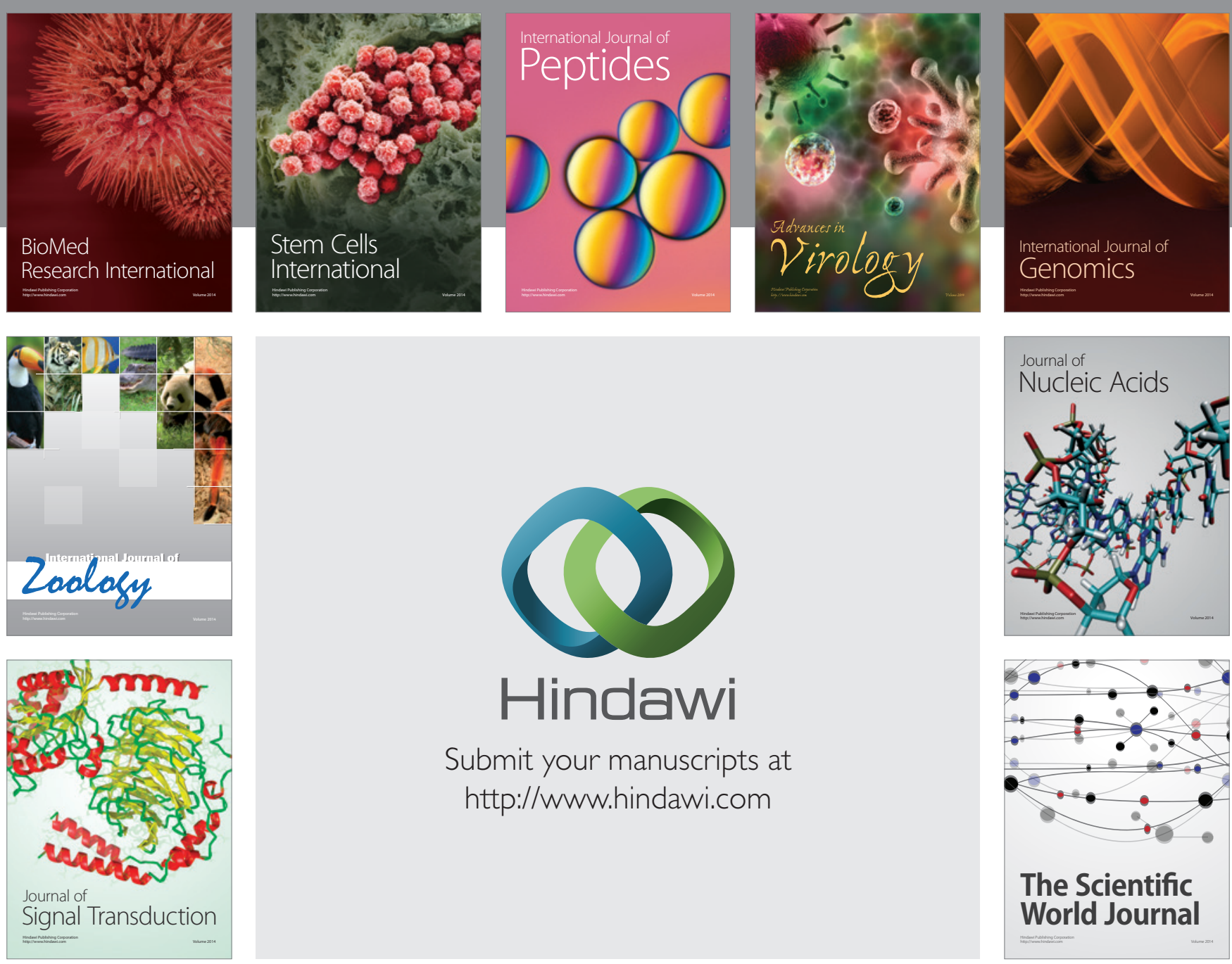

Submit your manuscripts at

http://www.hindawi.com
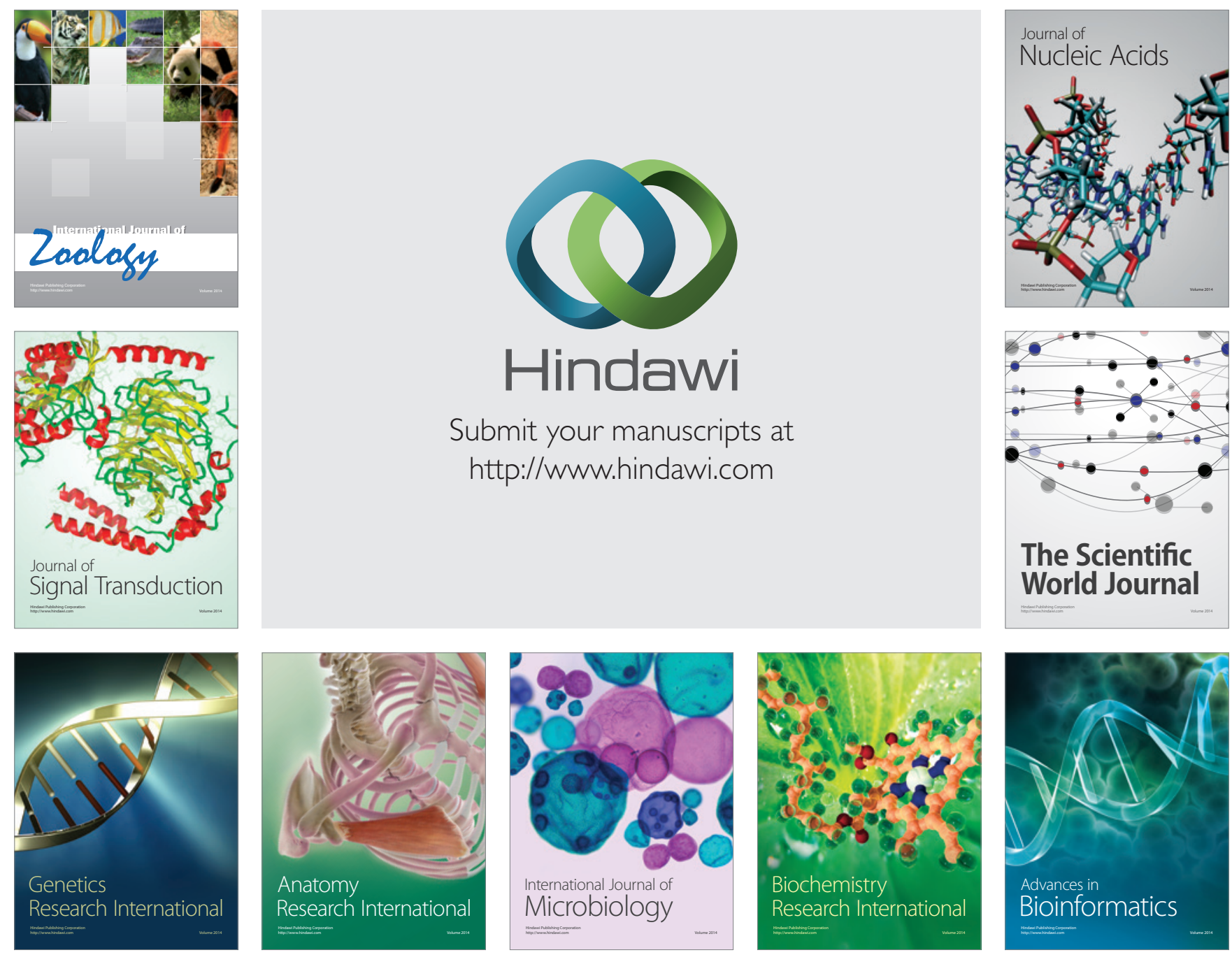

The Scientific World Journal
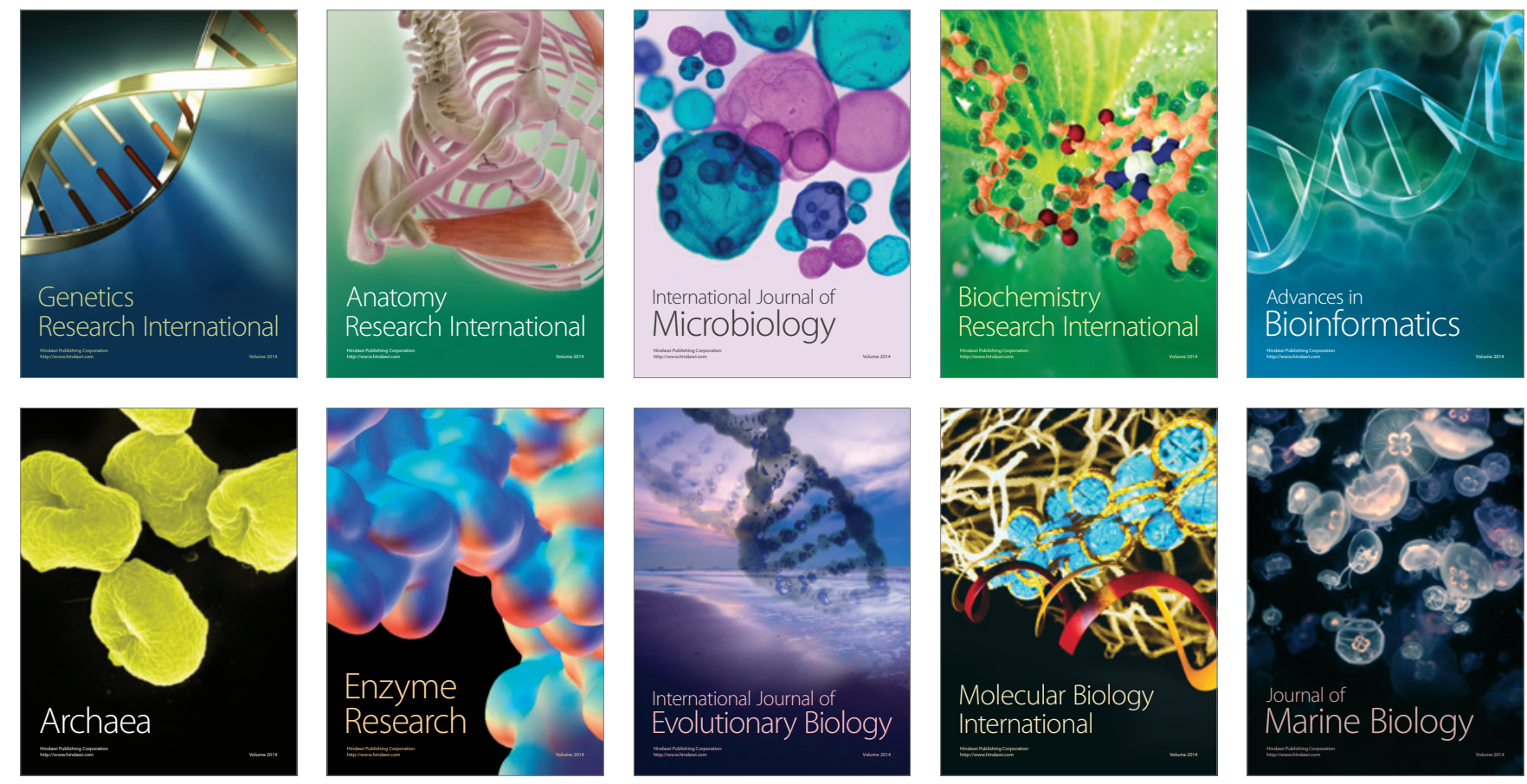